Paweł Ścigaj

Uniwersytet Jagielloński w Krakowie

\title{
Psychologiczne podstawy konfliktów społecznych: wokół dyspozycyjnych i sytuacyjnych mechanizmów wrogości i uprzedzeń
}

DOI: $10.19195 / 1643-0328.22 .8$

Słowa kluczowe: konflikty społeczne, konflikty polityczne, wrogość międzygrupowa, uprzedzenia, postawy polityczne

\section{Wprowadzenie}

Problematyka konfliktów społecznych, ekonomicznych, religijnych, kulturowych, a nade wszystko politycznych należy bez wątpienia do żelaznych tematów badań nauki o polityce. Nic w tym dziwnego. Jeśli powszechnie przyjmowaną i w zasadzie niekwestionowaną cechą zjawisk politycznych jest istnienie relacji władczych ${ }^{1}$, to wynikająca $z$ tego nierówność stron prowadzi do uznania konfliktów za powszechny aspekt polityki. Na ile konieczny, a na ile nie, na ile niepożądany, a na ile pożądany, na ile niszczący, a na ile (paradoksalnie) kreujący - to już kwestia innego rodzaju. Dość wspomnieć, że w naukach społecznych problemy te są przedmiotem sporu przynajmniej od czasów, gdy Marksowskiej idei konfliktu jako rozwoju społeczno-politycznego przeciwstawiono funkcjonalistyczne przekonanie o destrukcyjnym jego charakterze dla tkanki społecznej. Nie będę jednak tej pasjonującej i niezmiernie obszernej dyskusji w tym miejscu relacjonowal inni zrobili to lepiej, obszerniej i przede wszystkim bardziej kompetentnie ${ }^{2}$.

${ }^{1}$ Na ten temat zob. np.: J. Baszkiewicz, Władza, Wrocław 1999; K. von Beyme, Wspótczesne teorie polityczne, Warszawa 2005, s. 170-178; A. Czajowski, Władza polityczna. Analiza pojęcia, [w:] Studia z teorii polityki, red. A.W. Jabłoński, L. Sobkowiak, t. 1, Wrocław 1996, s. 31-52; R.A. Dahl, B. Stinebrickner, Współczesna analiza polityczna, Warszawa 2007, s. 29-50 oraz 61-87; J. Nocoń, A. Laska, Teoria polityki. Wprowadzenie, Warszawa 2005, s. 101-112; J. Scott, Władza, Warszawa 2006; J. Wiatr, Socjologia polityki, Warszawa 2009, s. $108-145$.

${ }^{2} \mathrm{Na}$ ten temat zob. np.: A. Adamus-Matuszyńska, Współczesne teorie konfliktu społecznego, Katowice 1998; H. Białyszewski, Teoretyczne problemy sprzeczności i konfliktów społecznych, Warszawa 1983; L.A. Coser, Funkcje konfliktu społecznego, Kraków 2009; R. Dahrendorf, Klasy i konflikt klasowy w społeczeństwie 
Rzeczą trywialną jest stwierdzić, że u podłoża konfliktów leży sprzeczność interesów $^{3}$. Rzecz się jednak komplikuje i przestaje być błaha, gdy zapytamy, jaka sprzeczność oraz jakich i czyich interesów. I znów, literatura przedmiotu jest bogata, gdy idzie o próby przybliżenia tej kwestii - i znów, nie będę jej tu szczegółowo relacjonował z powodów podobnych do wcześniej wymienionych. Dość powiedzieć, że powszechnie przyjęte jest rozróżnienie na interesy obiektywne i subiektywne, gdzie przez te pierwsze rozumie się najczęściej interesy wynikające z pozycji społeczno-ekonomicznej podmiotu, które nie zawsze muszą być uświadomione, te drugie zaś widziane są przez pryzmat wyobrażeń odnośnie do dóbr pożądanych i upragnionych, a przez to uświadomionych, które jednak wcale nie muszą wynikać z zajmowanej pozycji społeczno-ekonomicznej, a więc często nie są konsekwencją obiektywnej sprzeczności interesów ${ }^{4}$.

Bez względu na to, czy interes ma charakter obiektywny czy subiektywny, o jego zaistnieniu w procesie politycznym możemy mówić dopiero wówczas, gdy jest uświadomiony oraz gdy będąc wyartykułowanym, staje się podstawą podjęcia aktywności politycznej. Takie stanowisko odnaleźć można choćby w definicji zaproponowanej przez Ryszarda Herbuta, zgodnie z którą

interes polityczny to świadome pragnienie skierowania polityki publicznej jako całości lub poszczególnych decyzji dotyczących rozdziału wartości politycznych w konkretnym kierunku, postrzeganym przez zainteresowanego jako konieczny do osiągnięcia wcześniej uświadomionych i wyartykułowanych celów ${ }^{5}$.

Przyjęcie tego rodzaju przekonania rodzi wszakże szereg pytań. Bywa przecież, że cele nie są wyartykułowane, więcej jeszcze - wydają się w ogóle nieobecne. Idąc dalej, można zapytać, po pierwsze, dlaczego niektóre interesy obiektywne nie są uświadamiane, jak to się dzieje, np. w sytuacji, gdy kobiety nie buntują się przeciwko opresyjnym systemom społecznym? Po drugie, dlaczego spostrzegana sprzeczność interesów utrzymuje się niekiedy pomimo braku sprzeczności obiektywnej, jak to ma miejsce wówczas, gdy miłośnicy różnych klubów piłkarskich okazują sobie niechęć i to nawet w sytuacji braku faktycznego zaangażowania w doping oraz działania na rzecz klubu, i wreszcie po trzecie, czy obiektywna sprzeczność interesów jest w ogóle potrzebna, by konflikty wybuchały?

przemysłowym, Kraków 2008; idem, Nowoczesny konflikt społeczny: esej o polityce wolności, Warszawa 1993; Konflikt społeczny w perspektywie socjologicznej i pedagogiczno-psychologicznej: wybrane kwestie, red. D. Borecka-Biernat, M. Cywińska Warszawa 2015; M.K. Mlicki, Konflikty społeczne: pułapki i dylematy działań zbiorowych, Warszawa 1992; J. Mucha, Konflikt i społeczeństwo. Z problematyki konfliktu społecznego we wspótczesnych teoriach zachodnich, Warszawa 1978; My i oni: rola, miejsce i znaczenie konfliktów w polityce, red. A. Kasińska-Metryka, R. Miernik, cz. 1, Kielce 2010; My i oni: rola, miejsce i znaczenie konfliktów w polityce, red. A. Kasińska-Metryka, R. Miernik, cz. 2, Kielce 2012; L. Sobkowiak, Konflikt polityczny — analiza zjawiska, [w:] Studia z teorii polityki..., s. 117-131; J. Sztumski, Konflikt społeczny, Katowice 1987; idem, Konflikty społeczne i negocjacje jako sposoby ich przezwyciężania, Częstochowa 2000; J.H. Turner, Struktura teorii socjologicznej. Wydanie nowe, Warszawa 2004, s. 175-282.

${ }^{3}$ W.W. Wilmot, J.L. Hocker, Konflikty między ludźmi, Warszawa 2011, s. 103-105.

4 B. Kaczmarek, Polityka jako artykulacja interesów, [w:] Metafory polityki, red. idem, Warszawa 2001, s. $49-56$.

${ }^{5}$ R. Herbut, Interes polityczny jako kategoria politologiczna, [w:] Studia z teorii polityki..., s. 55. 
Powyższe pytania pozostają, moim zdaniem, bez odpowiedzi dopóty, dopóki nie zasięgniemy opinii psychologów rozpatrujących mechanizmy leżące u podstaw uprzedzeń, wrogości oraz dyskryminacji. Mając to na względzie, za cel tego artykułu przyjąłem krótkie, z konieczności, przedstawienie najważniejszych według mnie teorii rozwijanych na polu psychologii polityki, które próbują opisywać i wyjaśniać zjawiska międzygrupowej wrogości będącej ostatecznie niezbywalnym elementem behawioralnym każdego konfliktu społeczno-politycznego. Tekst ten ma więc charakter przeglądowy, acz nie ma roszczeń - co należy podkreślić - do wyczerpującego przedstawienia zagadnienia i to z trzech powodów: po pierwsze, takie zestawienie nie wydaje się możliwe, albowiem liczba koncepcji pojawiających się na gruncie psychologii polityki, a odnoszących się do interesujących nas tu zagadnień, jest bardzo duża i tworzenie jakiejkolwiek ich listy wydaje się z góry skazane na porażkę i zarzut niekompletności, wybiórczości, arbitralności doboru; po drugie, nie wydaje się to także potrzebne, ostatecznie bowiem tylko niektóre z ogłaszanych koncepcji zyskują uznanie innych badaczy, są teoretycznie znaczące i empirycznie dobrze zweryfikowane. Powód trzeci jest natury pragmatycznej, oto bowiem lepiej przedstawić kilka koncepcji najbardziej znaczących, aniżeli zdawkowo opisać jak najwięcej z nich.

Dodać jeszcze warto, że znacznie szerszej analizy wrogości w stosunkach politycznych podjął się z sukcesem Jacek Ziółkowski ${ }^{6}$. Niniejszy artykuł stanowi swego rodzaju glosę do jego pracy.

\section{Wrogość międzygrupowa jako fundament konfliktów społecznych}

Pojęcie wrogości posiada w naukach społecznych wiele odniesień i w różny sposób jest definiowane. Prezentując semantyczne pole pojęcia, Ziółkowski wspomina o wrogości m.in. jako o postawie, stereotypie, relacji, stosunku społecznym czy zachowaniu ${ }^{7}$. W moim odczuciu kluczowe jest myślenie pierwszego rodzaju przedstawiające wrogość jako pewnego rodzaju postawę. Jeśli przypomnimy sobie powszechnie przyjmowaną definicję postawy, w której wyróżnia się trzy jej komponenty, tj. wiedzę, ocenę i zachowanie $^{8}$, to wypada zauważyć, że w literaturze psychologicznej często wiąże się aspekt poznawczy ze stereotypami, afektywny z uprzedzeniami, behawioralny zaś z dyskryminacją ${ }^{9}$. Innymi słowy, stereotypy obejmują zespół specyficznych cech przypisanych danej grupie, które są rozpoznawane jako charakterystyczne dla niej, uprzedzenia są związane z oceną grupy, dyskryminacja zaś ze sposobem traktowania jej członków. Tworzą one ra-

${ }^{6}$ J. Ziółkowski, Wrogość w stosunkach politycznych. Modelowa analiza funkcjonalna, Warszawa 2013.

7 Ibidem, s. 54-59.

8 Zob. np.: S. Nowak, Pojęcie postawy w teoriach i stosowanych badaniach społecznych, [w:] Teorie postaw, red. idem, Warszawa 1973, s. 23; M. Marody, Sens teoretyczny a sens empiryczny pojęcia postawy. Analiza metodologiczna zasad doboru wskaźników w badaniach nad postawami, Warszawa 1976, s. 16-22; G. Böhner, M. Wänke, Postawy i zmiana postaw, Gdańsk 2004, s. 17-18.

9 T.D. Nelson, Psychologia uprzedzeń, Gdańsk 2003, s. 28. 
zem szeroko pojmowane postawy grupowe i są formą stronniczości międzygrupowej ${ }^{10}$. Jeśli owa stronniczość ma charakter negatywny, tj. ocena grupy jest negatywna i towarzyszą temu przejawy negatywnego zachowania, to mamy do czynienia z wrogością międzygrupową ${ }^{11}$.

Przyjmując powyższe rozstrzygnięcia definicyjne $-\mathrm{z}$ konieczności powierzchowne i problematyczne - można bez większego ryzyka błędu uznać, że kluczowe dla pojawiania się wrogości międzygrupowej są negatywne stereotypy, uprzedzenia oraz przejawy dyskryminacji, teorie, które je opisują i wyjaśniają, stanowią zaś dla nas istotne źródło wiedzy o powodach powstawania (lub niepowstawania), rozwijania się i wygaszania konfliktów społecznych. Krótko: jeśli u źródeł zjawisk politycznych leżą konflikty, a u ich podłoża wrogość międzygrupowa przejawiająca się w stereotypach, uprzedzeniach i dyskryminacji, to chcąc przedstawić psychologiczne mechanizmy tworzenia i rozwiązywania konfliktów, musimy przyjrzeć się teoriom powstałym na gruncie psychologii polityki, które mówią o tym, dlaczego nie lubimy innych, traktujemy ich jako obcych i często gorszych.

Które więc teorie psychologiczne wpisują się w powyższą charakterystykę i mogą być użyteczne w wyjaśnianiu konfliktów politycznych? Krystyna Skarżyńska powiada, że ważne są tu dwie perspektywy - teoria realistycznych konfliktów oraz teoria tożsamości społecznej $^{12}$. Janusz Reykowski dodaje do tego, że ważne jest skupienie się również na teoriach podnoszących zagadnienie różnic światopoglądowych, takich jak teoria opanowywania trwogi ${ }^{13}$. John Duckitt widzi sprawę jeszcze szerzej i powiada, że obok wyżej wzmiankowanych teorii, które można zaliczyć do grupy teorii sytuacyjnych, wielką rolę w powstawaniu uprzedzeń, dyskryminacji, wrogości i konfliktów społecznych odgrywają także czynniki dyspozycyjne ${ }^{14}$. Innymi słowy, przyczyn konfliktów oraz ich trwałości można upatrywać w dynamice zjawisk międzygrupowych, gdzie są one konsekwencją określonej sytuacji, swego rodzaju okoliczności, momentu, który uruchamia zjawiska stronniczości, a zwłaszcza wrogości, oraz w cechach indywidualnych, o których kiedyś sądzono, że stanowią elementy osobowości. Co za tym idzie, warto się przyjrzeć obu tym grupom teorii, przy czym rozważania dalsze odwrócimy, rozpoczynając od czynników dyspozycyjnych.

10 J.F. Dovidio et al., Prejudice, Stereotyping and Discrimination: Theoretical and Empirical Overview, [w:] The Sage Handbook of Prejudice, Stereotyping and Discrimination, red. idem et al., London 2013, s. 5-10.

11 J. Duckitt, Uprzedzenia i wrogość między grupami, [w:] Psychologia polityczna, red. D.O. Sears, L. Huddy, R. Jervis, Kraków 2008, s. 513.

${ }^{12}$ K. Skarżyńska, Wprowadzenie - Czym jest konflikt, od czego zależy jego przebieg i sposób rozwiazywania, [w:] Konflikty międzygrupowe. Przejawy, źródła i metody rozwiązywania, red. eadem, U. Jakubowska, J. Wasilewski, Warszawa 2007, s. 12.

13 J. Reykowski, Konflikty polityczne, [w:] Podstawy psychologii politycznej, red. K. Skarżyńska, Poznań 2002, s. 212-219.

14 J. Duckitt, op. cit., s. 526. 


\section{Dyspozycyjne mechanizmy wrogości międzygrupowej}

Spośród wielu koncepcji upatrujących w różnicach indywidualnych przyczyn wrogości wobec innych warto skupić się na dwóch. Idzie tu, po pierwsze, o teorię autorytaryzmu oraz, po drugie, o teorię dominacji społecznej, w ramach której pojawia się koncepcja orientacji na dominację społeczną.

Historia refleksji nad autorytaryzmem bierze swój początek w burzliwych czasach międzywojennych w Niemczech. W roku 1929 Erich Fromm przeprowadził badania w grupach robotników i służby domowej, odkrywając, że spośród trzech wyróżnionych przez niego charakterów: typu radykalnego, typu kompromisowego oraz typu autorytarnego, ten ostatni był szczególnie częsty pośród osób popierających NSDAP. Co ciekawe, Fromm wstrzymywał się z publikacją wyników tych badań aż do roku $1980^{15}$, co nie oznacza, że porzucił zainteresowanie psychologicznymi podstawami nazizmu. Gwoli kronikarskiej ścisłości trzeba jednak dodać, że jego rozważania na ten temat zostały wyprzedzone przez Wilhelma Reicha, który w roku 1933 opublikował Psychologię mas wobec faszyzmu, stwierdzając w niej, że partie faszystowskie mają szczególne wsparcie w „,człowieku maszynowym”, którego uległość wobec autorytetów i władzy wynika z tłumienia seksualności, głównie przez tradycyjną rodzinę, patriarchalizm oraz powszechną religijność ${ }^{16}$.

Koncepcja autorytaryzmu Ericha Fromma jest na najogólniejszym poziomie podobna do idei wyrażonych przez Reicha. Wynika to, rzecz jasna, nie tylko ze zbieżności problemu badawczego, ale przede wszystkim z przyjęcia tej samej psychoanalitycznej koncepcji osobowości mającej uzupełnić marksistowską perspektywę opisywania procesów społeczno-politycznych i pozwalającej zrozumieć związek pomiędzy psychicznymi potrzebami jednostki a ideologią i strukturą ${ }^{17}$. Ten punkt wyjścia prowadził jednak ówczesnych badaczy do przedstawiania autorytaryzmu jako typu osobowości targanej wewnętrznymi konfliktami, w których jak w soczewce odbijały się uwarunkowania społeczno-historyczne tamtych czasów ${ }^{18}$. Nie inaczej dzieje się w koncepcji Fromma, który rozważa autorytaryzm jako jedną z trzech - obok destruktywności i mechanicznego konformizmu - form ucieczki od wolności. Niemiecki psycholog uważał, że wraz z postępem cywilizacji rośnie, z jednej strony, sfera ludzkiej wolności i możliwości działa-

15 J. Baars, P. Scheepers, Theoretical and methodological foundations of the authoritarian personality, „Journal of the History of the Behavioral Science” 1993, nr 29, s. 346.

16 Upraszczając (być może przesadnie), można ów mechanizm tworzenia człowieka autorytarnego opisać następująco: tłumiona i represjonowana seksualność wyzwala w jednostce poczucie winy za grzeszne myśli i czyny, które jest łagodzone i niwelowane przez surowe nakazy i zakazy, prowadząc, w konsekwencji, do agresji wobec obcych oraz do posłuszeństwa wobec władzy rodzicielskiej, zwłaszcza ojcowskiej oraz religijnej. Idąc dalej, można powiedzieć, że silna ręka ojca na poziomie działań zbiorowych przeradza się w silną rękę państwa, której jednostka słucha i jest podporządkowana. W. Reich, Psychologia mas wobec faszyzmu, Warszawa 2009, s. 13-31 oraz 113-146.

17 J. Koralewicz, Autorytaryzm, lęk, konformizm, Warszawa 2008, s. 136-137.

18 M.P. Worell, Authoritarianism, critical theory, and political psychology: Past, present, future, „Social Thought \& Research" 1998, nr 21 (1-2), s. 3-6. 
nia oraz, z drugiej strony, lęk i przerażenie nowym, nieznanym, zagrażającym. Wolność wymaga odpowiedzialności, dojrzałości i samodzielności, a skoro tak, to osoby niepotrafiące odnaleźć poczucia bezpieczeństwa w świecie przemysłowym wyrzekną się jej, podobnie jak i własnej autonomii ${ }^{19}$. A zatem źródłem autorytaryzmu, destrukcyjności oraz mechanicznego konformizmu jest lęk przed światem i przekonanie, że nie sposób stawić mu czoła ${ }^{20}$.

Charakterystycznym rysem autorytaryzmu, jako formy ucieczki od wolności, jest wewnętrzny konflikt. Oto bowiem człowiek autorytarny osiąga poczucie bezpieczeństwa w dialektycznym mechanizmie wyrzekania się siebie i stapiania się ze światem całkowitego podporządkowania się władzy oraz wielkiego pragnienia jej posiadania. Innymi słowy, osobowość autorytarna to osobowość sadomasochistyczna, przy czym ani sadyzm, ani masochizm nie są tu widziane w kategoriach zaburzeń seksualnych, lecz jako powszechne i przejawiające się w codziennych działaniach. Co ważne, tak masochizm, jak sadyzm są formą zanegowania ,ja”, gdzie owo „ja” ginie zatopione w „my”, tyle że w przypadku pierwszym idzie wprost o zaprzeczenie podmiotowości jednostki, w drugim zaś mechanizm jest subtelniejszy i poniekąd paradoksalny, albowiem wyrzeknięcie się autonomii następuje poprzez stopienie się z osobą podporządkowaną - sadysta nie jest wcale panem swojego „ja”, jest panem swojego „my”21. To, co wydaje się szczególnie ważne z perspektywy naszych rozważań, to przekonanie Fromma, że osoby autorytarne cechuje uległość i podporządkowanie wobec autorytetów, ale także chęć bycia autorytetem; są oni skłonni ograniczać ludzką wolność, stosują podwójne standardy, i zasadniczo nie lubią „,innych”, „obcych"22.

Powyższe kwestie są także widoczne w bodaj najbardziej znanej koncepcji osobowości autorytarnej przedstawionej przez Theodora W. Adorna wraz z Elsą Frenkel-Brunswik, Danielem J. Levinsonem oraz R. Nevittem Sanfordem. Jest to chyba najlepiej omówiona teoria autorytaryzmu, więc nie będę zatrzymywał się nazbyt szczegółowo na jej elementach, przypomnę jedynie, że według Adorna autorytaryzm jest syndromem składającym się z dziewięciu cech: konwencjonalizmu, autorytarnego podporządkowania, autorytarnej agresji, antyintracepcji, przesądu i stereotypu, kultu siły i „twardego charakteru", destrukcyjności i cynizmu, skłonności do projekcji oraz seksualności ${ }^{23}$.

19 E. Fromm, Ucieczka od wolności, Warszawa 2008, s. 40-108.

20 K. Stenner, The Authoritarian Dynamic, Cambridge 2005, s. 143.

21 E. Fromm, op. cit., s. 145-160. Można dodać, że w kolejnych pracach poglądy Fromma ewoluowały, czego jednak nie będę tu szczegółowo relacjonował. Dość powiedzieć, że upatrywał on przyczyn autorytaryzmu w dominacji popędu śmierci, co było wpisane w szerszy plan starcia „modusu bycia” i „modusu posiadania" - wielkiej walki Erosa i Tanatosa. E. Fromm, Mieć czy być?, Poznań 2000, s. 133-135 oraz 147-148; idem, Anatomia ludzkiej destrukcyjności, Poznań 1999, s. 366-401.

22 E. Fromm, Ucieczka od wolności..., s. 161-172.

23 Adorno następująco definiuje poszczególne składowe syndromu autorytarnego: „A. Konwencjonalizm. Sztywne przywiązanie do konwencjonalnych wartości klasy średniej. B. Autorytarne podporządkowanie. Uległa i bezkrytyczna postawa wobec wyidealizowanych autorytetów moralnych danej grupy. C. Autorytarna agresja. Tendencja do nieufnego traktowania, oceniania, odrzucania i karania ludzi, którzy łamią konwencjonalne wartości. D. Antyintra cepcja. Sprzeciw wobec tego, co subiektywne, wyobrażeniowe i związane z wrażliwością. E. Przesąd i stereotyp. Wiara w mistyczną determinację 
Wyszczególnienie tych cech nie oznacza, iż Adorno nie podzielał przekonania Fromma o sadomasochistycznym rysie autorytaryków. Kształtowanie się osobowości autorytarnej dokonuje się w rodzinie, w której przeważają surowe i zimne relacje, powszechna jest agresja i kary cielesne, a także wymóg bezwzględnego posłuszeństwa wobec rodziców ${ }^{24}$. Pierwotna miłość dziecka do matki zostaje poddana tabuizacji, albowiem dziecko nie może jej wyrażać w sposób dowolny i spontaniczny. Uczucia negatywne kierują się więc w stronę surowego ojca, jednak także ich okazywanie jest niemożliwe ze względu na spodziewane kary. Dziecko zaczyna odczuwać wobec rodziców ambiwalentne uczucia: kocha ich i nienawidzi, podporządkowuje się i buntuje, dostrzega ich łagodność i okrucieństwo, współczucie i bezduszność itp. W takiej sytuacji utrzymanie miłości do rodziców wymaga separacji przeciwstawnych impulsów i skierowania tych pozytywnych do wewnątrz, co objawia się bezkrytyczną i bezwarunkową idealizacją rodziców przez osoby autorytarne, a tych negatywnych - na zewnątrz, co skutkuje wrogością, nienawiścią i agresją wobec „innych”, „obcych”25. Widać tu zbieżność z poglądami Fromma, albowiem autorytaryk staje się masochistyczny wobec autorytetu ojca (władzy) oraz sadystyczny wobec „obcych" 26 .

Powyżej opisane „klasyczne” koncepcje osobowości autorytarnej, a zwłaszcza teoria przedstawiona przez Adorna, doczekały się licznych głosów krytycznych. Były one związane z problemami pomiaru, błędami metodologicznymi oraz kłopotami teoretycznymi wynikającymi z przyjęcia psychoanalitycznej teorii osobowości, kwestii tych nie będę jednak w tym miejscu szczegółowo rozwijał ${ }^{27}$. Skupię się na jednym z zarzutów, który dał impuls do dalszych badań. Idzie o to, że dla Reicha, Fromma i Adorna autorytaryzm był nieodmiennie związany z ideologią prawicową - to osoby wspierające partie prawicowe i posiadające poglądy konserwatywne stanowily punkt odniesienia dla owych koncepcji i to one były przez nie opisywane. W latach 50 . XX w. zakwestionowano ten pogląd. Najpierw Edward Shils, później Hans J. Eysenck, a wreszcie Milton Rokeach argumentowali (głównie z pozycji behawioralnych i poznawczych), że autorytaryzm jest niewrażliwy ideowo i cechuje tak zwolenników prawicy, jak lewicy ${ }^{28}$. Idąc tym tropem, Eysenck wy-

indywidualnego losu. Skłonność do myślenia sztywnymi kategoriami. F. Kult siły i »twardy charakter «. Myślenie w kategoriach dominacja/podporządkowanie, silny/słaby, przywódca/wykonawca; identyfikacja z figurami władzy; nadmierne podkreślanie skonwencjonalizowanych atrybutów ego; przesadne manifestowanie siły i »twardego charakteru«. G. Destrukcyjność i cynizm. Ogólna wrogość, pogarda do człowieka. H. Skłon ność do projekcji. Wiara w to, że na świecie dzieją się rzeczy niecodzienne i niebezpieczne. Projekcja na zewnątrz nieświadomych impulsów emocjonalnych. I. Seksualność. Przesadne zainteresowanie »czynnościami seksualnymi«". T.W. Adorno, Osobowość autorytarna, Warszawa 2010, s. 45.

${ }^{24}$ U. Jakubowska, Ekstremizm polityczny. Studium psychologiczne, Gdańsk 2005, s. 42.

25 Ibidem, s. 318-322.

26 D. Held, Introduction to Critical Theory. Horkheimer to Habermas, Berkeley-Los Angeles 1980, s. 144.

27 P. Radkiewicz, Autorytaryzm a brzytwa Ockhama, Warszawa 2012, s. 26-30; idem, Autorytaryzm jako ideologiczna wizja świata społecznego i jako postawa wobec własnej grupy. Co jest bliższe istoty zjawiska?, [w:] Wobec obcych. Zagrożenia psychologiczne a stosunki międzygrupowe, red. M. Kofta, M. Bilewicz, Warszawa 2011, s. 210.

28 M. Roiser, C. Willig, The strange death of the authoritarian personality: 50 years of psychological and political debate, „History of the Human Science” 2002, nr 15 (4), s. 80-81. 
różniał osoby o umysłowości miękkiej oraz osoby o umysłowości twardej, będące w istocie autorytarykami ${ }^{29}$. „Twardogłowi”, jak powiada Radkiewicz, chętniej popierają działania konfliktowe i prowadzenie wojen, a także czują się lepszymi od członków rozmaitych mniejszości, zwłaszcza narodowych ${ }^{30}$. Rokeach rozpoznał autorytaryków pośród osób mających umysł dogmatyczny, który cechuje sztywność poznawcza, nietolerancja poglądów innych niż własne, izolacja poszczególnych przekonań oraz wyolbrzymianie różnic pomiędzy poglądami. Dogmatycy są bezkrytyczni wobec „swoich” autorytetów, wiedzą znacznie więcej o grupie własnej niż o grupie obcej, oceniają innych podług zgodności przekonań z własnymi, miewają podwójne standardy, a gdy coś przeczy ich przekonaniom, wówczas zwyczajnie ignorują takie doświadczenia ${ }^{31}$. Innymi słowy, niechęć i wrogość wobec „obcych” wyjaśniana jest przez Rokeacha dogmatycznością umysłu, przy czym ona, podkreślmy raz jeszcze, nie ma koloru politycznego ${ }^{32}$. Warto jeszcze wspomnieć, że pomimo podkreślania poznawczych mechanizmów dogmatyzacji umysłu Rokeach pozostał dłużnikiem perspektywy psychoanalitycznej, gdy idzie o rozwój tej cechy. Podobnie do Adorna i innych, podkreślał, że dogmatyzm ma swoje źródła w traumach z dzieciństwa, wypartych lękach, ambiwalentnych uczuciach wobec rodziców ${ }^{33}$.

Nie ma tu potrzeby wnikliwie przedstawiać kolejnych dziesięcioleci rozwoju badań nad autorytaryzmem od lat 50. do 80. Trzeba jednak zatrzymać się nad koncepcją, która dała nowy impuls w tej historii, choć - co warto podkreślić - porzuciła myślenie o osobowości autorytarnej, przedstawiając ją jako postawę. Mowa tu, rzecz jasna, o teorii autorytaryzmu prawicowego Boba Altemeyera, według którego autorytaryzm jest kowariancją trzech cech opisanych wcześniej przez Adorna, tj. autorytarnego podporządkowania, autorytarnej agresji oraz konwencjonalizmu ${ }^{34}$. Co ważne, Altemeyer uważa, że wszyscy są w pewnym stopniu autorytarni, choć niektórzy wysoko, a inni nisko.

Badania prowadzone w kolejnych latach nad RWA (Right-Wing Authoritarianism) tak przez kanadyjskiego psychologa, jak licznych jego współpracowników i naśladowców pokazały zasadniczą słuszność koncepcji. Zgodnie z tymi badaniami osoby z wysokim RWA łatwiej tolerują nadużycia władzy, są bardziej obojętne wobec praw człowieka, są uległe i podporządkowane władzy i autorytetom, są gotowe surowo karać przestępców i różnego rodzaju odmieńców, są bardziej uprzedzone rasowo i etnicznie, wrogie wobec mniejszości oraz konformistyczne wobec tradycyjnych norm i praktyk społecz-

29 H.J. Eysenck, The Psychology of Politics, New Brunswick-London 1999, s. 131-132.

30 P. Radkiewicz, Autorytaryzm a brzytwa Ockhama..., s. 32-33.

31 Ibidem, s. 35-36; U. Jakubowska, op. cit., s. 46.

32 M. Rokeach, The Open and Closed Mind: Investigations into the Nature of Belief Systems and Personality Systems, New York 1960, s. 4-5.

33 R. Brown, Prejudice: It's Social Psychology, Oxford 2010, s. 22.

34 Definicje składowych postawy autorytarnej są następujące: „autorytarne podporządkowanie - wysoki poziom podporządkowania wobec autorytetów uznanych i legitymizowanych przez społeczeństwo, w którym jednostka żyje. Autorytarna agresja - ogólna wrogość skierowana wobec różnych osób, która jest usankcjonowana przez uznane autorytety. Konwencjonalizm - wysoki poziom przestrzegania konwencji społecznych postrzeganych, jako aprobowane przez społeczeństwo i uznane autorytety". B. Altemeyer, The Authoritarian Specter, London 1996, s. 6. 
nych, także dotyczących seksualności ${ }^{35}$; chętniej także popierają partie prawicowe, choć wielu autorytaryków wspiera partie lewicowe i centrowe, o czym warto pamiętać ${ }^{36}$.

„Konfliktowy potencjał” osób z wysokim RWA pokazały eksperymenty przeprowadzone przez Altemeyera w latach 90., w których prosił badanych o wzięcie udziału w grze mającej na celu rozwiązanie istotnych problemów na świecie. W grze tej symuluje się rozwój ludzkości przez kolejne 40 lat, bierze w niej udział ok. 70 graczy, którzy przypisani są do poszczególnych regionów i dysponują siłą polityczną, militarną i ekonomiczną analogiczną do ich realnej siły. Symulacja, w której udział brali respondenci z niskimi wynikami na skali RWA, przyniosła obiecujące wyniki: większość problemów światowych, takich jak walka z głodem, zmniejszenie bezrobocia, podniesienie jakości życia czy dbałość o środowisko, zostało rozwiązanych; jednocześnie gracze rozwinęli współpracę regionalną. Oczywiście pojawiały się różne problemy, np. śmierć 400 milionów osób w Afryce i w Indiach z powodu odmowy pomocy przez bogatsze regiony, jednak na koniec gry populacja ludzka wynosiła 8,7 miliarda osób i chyba można zasadnie powiedzieć, że żyła w świecie spokojniejszym niż ten, który badani zastali na początku gry. Kompletnie inne wyniki przyniosły symulacje z udziałem osób o wysokim RWA. Odbyły się dwie gry, albowiem koniec pierwszej nastąpił szybciej, niż planował Altemeyer, a to za sprawą nuklearnej zagłady. W drugiej grze broń nuklearna nie została już użyta, jednak liczne konflikty konwencjonalne i ich skutki pochłonęły 2,1 miliarda ofiar. Do tego trzeba dodać degradację ekologiczną planety, brak współpracy regionalnej oraz nierozwiązane problemy głodu, biedy i bezrobocia ${ }^{37}$. Nie można, rzecz jasna, traktować powyższych badań jako dowodu na szkodliwe działanie osób wysoko autorytarnych, co nie zmienia faktu, że w świetle badań psychologów osoby z wysokim RWA są bardziej konfliktowe i mniej skłonne do współpracy.

Koniec XX i początek XXI w. przyniosły nowe teorie autorytaryzmu wykraczające poza dotychczasowe badania. John Duckitt, a później Jost Stellmacher i Thomas Petzel zaczęli myśleć o autorytaryzmie nie jako o typie osobowości ani jako o postawie, lecz jako o wyobrażeniu na temat relacji między jednostką a społeczeństwem. Według Duckitta autorytaryzm jest jednym z końców kontinuum, którego przeciwieństwem jest libertarianizm. $\mathrm{W}$ tym pierwszym przypadku więc mamy do czynienia $\mathrm{z}$ zupełną dominacją

35 B. Altemeyer, op. cit., s. 22-38; P. Radkiewicz, Autorytaryzm a brzytwa Ockhama..., s. 50; U. Jakubowska, op. cit., s. 49-50.

36 Widać to także w Polsce, gdzie w badaniach przeprowadzonych przez CBOS przy użyciu bardzo skróconej skali (obejmującej niestety tylko 3 pozycje) okazało się, że najwyższy wynik uzyskały elektoraty Polskiego Stronnictwa Ludowego (3,43 na skali 1-5) oraz Prawa i Sprawiedliwości $(3,41)$, najniższy zaś zwolennicy Nowoczesnej Ryszarda Petru $(2,72)$ oraz Platformy Obywatelskiej $(2,97)$. Oznacza to, że o ile częściej napotkamy osoby autorytarne wśród wyborców PSL i PiS, o tyle wśród zwolenników Nowoczesnej oraz PO jest ich także bardzo dużo, najpewniej ponad 50\%. P. Ścigaj, Polacy 2015. Wybrane postawy polskiego społeczeństwa w roku wyborów prezydenckich i parlamentarnych, [w:] Oblicza kampanii wyborczych 2015 roku, red. M. Kułakowska, P. Borowiec, P. Ścigaj, Kraków 2016, s. 26-31; Psychologiczne charakterystyki elektoratów partyjnych, CBOS, Komunikat z badań nr 138/2015, Warszawa 2015, s. 9-11.

37 B. Altemeyer, What happens when authoritarians inherit the earth? A simulation, „Analyses of Social Issues and Public Policy" 2003, nr 3 (1), s. 161-169; idem, The Authoritarians, Winnipeg 2006, s. 30-34, http://members.shaw.ca/jeanaltemeyer/drbob/TheAuthoritarians.pdf (dostęp: 6 stycznia 2017). 
„my” nad „ja”, a w tym drugim odwrotnie ${ }^{38}$. Co za tym idzie, autorytaryzm nie jest żadną względnie stałą cechą dyspozycyjną, ale pojawia się jako konsekwencja zagrożenia wspólnotowej jedności, spójności i bytu, wyrażając się w uprzedzeniach międzygrupowych ${ }^{39}$.

Duckitt, głównie pod wpływem krytyki Johna J. Raya, porzucił swoją teorię autorytaryzmu $^{40}$, jednak nie została ona zupełnie zapomniana, stając się punktem wyjścia teorii autorytaryzmu grupowego Stellmachera i Petzela. Oni także wiążą siłę autorytaryzmu z poczuciem zagrożenia tożsamości społecznej w określonych sytuacjach, co uzależnia go od czynników historycznych, kulturowych oraz kontekstu procesów grupowych. Mechanizm funkcjonowania autorytaryzmu można opisać tu następująco: ludzie różnią się pod względem dyspozycji autorytarnej (zoperacjonalizowanej jako RWA), a skoro tak, to w sytuacji zagrożenia będą reagować odmiennie, to znaczy osoby o wyższym RWA będą ujawniały silniejsze cechy autorytarne. Autorytaryzm nie jest więc stałą cechą podmiotu, lecz jedynie ujawnianą $\mathrm{w}$ zależności od sytuacji reakcją na zagrożenie przejawiającą się w konformizmie wobec norm grupowych, uległością wobec liderów grupy własnej oraz nietolerancją odmienności ${ }^{41}$.

Konkludując powyższe wątki, warto przypomnieć, że badania nad autorytaryzmem mają niezwykle bogatą historię w psychologii polityki: począwszy od osobowości, poprzez postawę, aż po ujawnianą sytuacyjnie cechę myślenia grupowego. Bez względu jednak na różnice teoretyczne i metodologiczne w badaniach nad autorytaryzmem jedna rzecz jest wspólna wszystkim koncepcjom: wszystkie one widzą autorytaryków jako osoby o wysokim poziomie uprzedzeń i skłonności do konfliktów, często są nastawione wrogo i agresywnie wobec innych, obcych. Niemniej jednak według niektórych badaczy osoby autorytarne nie są prowodyrami, liderami, przywódcami - są najczęściej wykonawcami woli innych: są wrodzy, ale ktoś musi im wskazać wroga, rzucą kamieniem, ale muszą wiedzieć w kogo. Tym „kimś”, kto powie im, w kogo „rzucić kamieniem”, są osoby o wysokiej orientacji na dominację społeczną.

Orientacja na dominację społeczną (Social Dominance Orientation - SDO) to dyspozycyjny mechanizm podtrzymywania dominacji grupowej odnoszący się do ogólnych preferencji co do równości-hierarchiczności relacji międzygrupowych, a dokładniej do pragnienia, aby grupa własna dominowała nad grupami obcymi ${ }^{42}$. Idea SDO została sformułowana $\mathrm{w}$ ramach teorii dominacji społecznej przez Jima Sidaniusa oraz Felicię Pratto. Teoria ta przyjmuje, że istnieją trzy rodzaje hierarchii społecznej: dwie są uniwersalne i oparte na płci oraz wieku, trzecia ma zaś charakter arbitralny i pojawia się wyłącznie w społeczeństwach wytwarzających stałą nadwyżkę dóbr. Czynnikiem

38 J. Duckitt, Authoritarianism and group identification: A new view of an old construct, „Political Psychology" 1989, nr 10 (1), s. 71.

39 Ibidem, s. 75-78.

40 J.J. Ray, Authoritarianism and group identification: A new view of an old construct: Comment, „Political Psychology" 1990, nr 11 (3), s. 629-632.

41 J. Stellmacher, T. Petzel, Authoritarianism as a group phenomenon, „Political Psychology” 2005, nr 26 (2), s. 248-249 oraz 252-253.

42 J. Sidanius, F. Pratto, Social Dominance. An Intergroup Theory of Social Hierarchy and Oppression, Cambridge 1999, s. 61. 
hierarchii arbitralnych może być potencjalnie dowolna cecha społeczna, choć dziś najczęściej są to czynniki etniczne, narodowe, religijne, klasowe i regionalne. Co wydaje się zupełnie jasne, beneficjenci systemów hierarchicznych będą dążyli do ich ochrony i podtrzymania ${ }^{43}$. Zgodnie z SDT (Social Dominance Theory) wrogość międzygrupowa i dyskryminacja mogą pojawiać się na trzech poziomach, tj. systemowym, grupowym oraz personalnym. Owe poziomy wyrażają się odpowiednio w instytucjach społecznych, ideologiach, wzorach zachowań i normach czy konkretnych aktach agresji4 ${ }^{4}$. Łączą je mity legitymizacyjne, które można zdefiniować jako podzielane społecznie ideologie oraz stereotypy. Teoria dominacji społecznej mówi o dwóch rodzajach takich mitów: pierwsze z nich podtrzymują hierarchie społeczne (np. seksizm, rasizm, nacjonalizm i inne), drugie ją osłabiają (np. idee równościowe ${ }^{45}$. Innymi słowy, mity legitymizacyjne funkcjonują podobnie do Marksowskiej fałszywej świadomości ${ }^{46}$.

Jak łatwo się domyślić, osoby o wysokim SDO należą do szczególnie uprzedzonych oraz skłonnych do dyskryminacji słabszych i zajmujących niższą pozycję społeczną. Są to częściej mężczyźni niż kobiety, choć te ostatnie również mogą notować wysokie wyniki na skali SDO, o ile wspierają prohierarchiczne mity legitymizacyjne ${ }^{47}$. Warto podkreślić, że wysokie SDO koreluje pozytywnie z wysokim poziomem uprzedzeń etnicznych, szowinizmem, konserwatyzmem, autorytaryzmem, nacjonalizmem, seksizmem, antyegalitaryzmem, niechęcią wobec programów pomocowych dla słabszych, infrahumanizacją obcych, odmową pomocy dla imigrantów, poparciem dla kary śmierci, zawieszeniem praw obywatelskich $\mathrm{w}$ związku $\mathrm{z}$ koniecznością walki $\mathrm{z}$ terroryzmem, poparciem dla wojny w Iraku, zakwestionowaniem równouprawnienia kobiet i gejów, a także wsparciem mitów legitymizujących, takich jak przekonanie, że ofiary gwałtów są częściowo winne swojej sytuacji, wyborem zawodów prohierarchicznych i rywalizacyjnych ${ }^{48}$.

43 Ibidem, s. 38; F. Pratto et al., Social dominance orientation: A personality variable predicting social and political attitudes, „Journal of Personality and Social Psychology” 1994, nr 67 (4), s. 741; J. Sidanius, F. Pratto, Social Dominance Theory, [w:] Handbook of Theories of Social Psychology, red. P.A.M. van Lange, A.W. Kruglanski, E.T. Higgins, t. 2, London 2012, s. 418-419.

44 F. Pratto, J. Sidanius, S. Levin, Social dominance theory and the dynamics of intergroup relations: Taking stock and looking forward, „European Review of Social Psychology” 2006, nr 17 (1), s. 272; J. Sidanius, F. Pratto, Social Dominance Theory..., s. 419-420.

45 S. Levin et al., Ethnic identity, legitimizing ideologies, and social status: A matter of ideological asymmetry, „Political Psychology” 1998, nr 19 (2), s. 376-377; F. Pratto et al., Social dominance orientation..., s. $742-743$.

46 J. Sidanius, F. Pratto, Social Dominance Theory..., s. 426.

47 J. Sidanius et al., Social dominance orientation, anti-egalitarianism and the political psychology of gender: an extension and cross-cultural replication, „European Journal of Social Psychology” 2000, nr 30, s. 58-59; F. Pratto et al., Social dominance orientation..., s. 742 oraz 755.

48 F. Pratto et al., Social dominance orientation..., s. 755-758; J. Sidanius, F. Pratto, Social Dominance Theory..., s. 432-433; K. Costello, G. Hodson, Social dominance-based threat reactions to immigrants in need of assistance, „European Journal of Social Psychology” 2011, nr 41, s. 228-230; J.S. Trounson, C. Critchley, J.E. Pfeifer, Australian attitudes toward asylum seekers: Roles of dehumanization and social dominance theory, „Social Behavior and Personality” 2015, nr 43 (10), s. 1650-1651. 
Odnosząc się do badań nad SDO, Altemeyer zauważył, że osoby z wysokim SDO wydają się być najbardziej uprzedzonymi spośród do tej pory opisanych ${ }^{49}$. Uważał on także, że RWA i SDO prezentują dwie postaci postawy autorytarnej, tj. podporządkowaną oraz dominującą - ci pierwsi słuchają, drudzy rozkazują i przewodzą. Sądził też, że zdarza się niekiedy, choć jest to niezwykle rzadkie, iż jedna osoba uzyskuje wysokie wyniki na obu skalach. Tacy „podwójnie wysocy” są bardzo uprzedzeni i mają wielkie możliwości przywódcze, co czyni z nich doskonałych liderów najczęściej prawicowych ruchów politycznych; zdaniem Altemeyera takim „podwójnie wysokim” był Adolf Hitler ${ }^{50}$.

Stanowisko kanadyjskiego psychologa wydaje się odosobnione; wielu badaczy skłania się do przekonania, że RWA i SDO nie mogą być atrybutem jednej osoby, choć są one pewnie jakoś połączone. Idea ta została bodaj najpełniej wyrażona w modelu podwójnego procesu zaproponowanym przez Duckitta. Jego zdaniem RWA i SDO są postawami opartymi w odmiennych wizjach rzeczywistości i różnych motywacjach. W przypadku pierwszym świat jest spostrzegany jako miejsce niebezpieczne i pełne zagrożeń, a jednostka dąży do uzyskania poczucia bezpieczeństwa i spójności społecznej. W przypadku drugim świat jest widziany w kategoriach bezwzględnej rywalizacji i walki, gdzie wyłącznie siła decyduje o pozycji, a skoro tak, to osoby z wysokim SDO dążą do dominacji i władzy nad innymi ${ }^{51}$. Co ważne, zarówno RWA, jak i SDO skutkują wrogimi i konfliktowymi postawami wobec grupy obcej.

Powyższe rozważania nie wyczerpują bogatej debaty nad dyspozycyjnymi mechanizmami wrogości międzygrupowej. Obejmuje ona cały szereg innych jeszcze koncepcji, np. paranoję polityczną ${ }^{52}$, nietolerancję wieloznaczności ${ }^{53}$ czy potrzebę domknięcia poznawczego ${ }^{54}$. Jednak nawet jeśli te, jak również inne idee dopełniłyby obraz powodów, dla których ludzie są gotowi nienawidzić innych i podtrzymują tę gotowość niekiedy bez wyraźnych powodów, to ich omówienie w tym miejscu nie jest potrzebne. Powyższy obraz wydaje się już wystarczająco bogaty. Oto bowiem wysokie RWA lub wysokie SDO pozwala łatwo przewidzieć wrogość wobec obcych, gotowość do ich karania, krzyw-

49 B. Altemeyer, What happens when authoritarians inherit the earth?..., s. 163.

50 B. Altemeyer, The Other „Authoritarian Personality”, [w:] Political Psychology. Key Readings, red. J.T. Jost, J. Sidanius, New York-Hove 2004, s. 105.

51 J. Duckitt, A Dual-Process Cognitive-Motivational Theory of Ideology and Prejudice, [w:] Advances in Experimental Psychology, t. 33, red. M. Zanna, New York 2001, s. 50; J. Duckitt, Uprzedzenia i wrogość między grupami..., s. 529-532.

$52 \mathrm{Na}$ ten temat zob. m.in.: M. Grzesiak-Feldman, Psychologia myślenia grupowego, Warszawa 2016; K. Korzeniowski, Polska paranoja polityczna. Źródła, mechanizmy i konsekwencje spiskowego myślenia o polityce, Warszawa 2010; D. Pipes, Potega spisku. Wpływ paranoicznego myślenia na dzieje ludzkości, Warszawa 1998; R.S. Robins, J.M. Post, Paranoja polityczna. Psychologia nienawiści, Warszawa 2007; Struktura teorii spiskowych. Antologia, red. F. Czech, Kraków 2014.

$53 \mathrm{Na}$ ten temat zob. E. Frenkel-Brunswick, Intolerance of ambiguity as an emotional and perceptual personality variable, „Journal of Personality” 1949, nr 18 (1); U. Jakubowska, op. cit., s. 55.

${ }^{54} \mathrm{Na}$ ten temat zob.: A.W. Kruglanski, D.M. Webster, Motivated closing of the mind: „Seizing” and "freezing”, „Psychological Review” 1996, nr 103 (2); M. Kossowska, O motywach sprzyjających vs. przeciwdziałających powstawaniu uprzedzeń, „Psychologia Społeczna” 2006, nr 2 (2); eadem, Różnice indywidualne w potrzebie poznawczego domknięcia, „Przegląd Psychologiczny” 2003, nr 103 (2). 
dzenia oraz dyskryminacji, wskazując tym samym, że konflikty mogą być „łatwiejsze”, głębsze, bardziej długotrwałe, jeśli tylko jednostka posiada pewne cechy, utrudniające jej otwartą współpracę i wzajemne poszanowanie. Jednak czy zawsze jest tak, że to jabłko jest zgniłe? Może, nawiązując do znanych wniosków z eksperymentu stanfordzkiego Philipa Zimbarda, to skrzynka sprawia, że nawet najzdrowsze jabłko zgnije? ${ }^{55}$ Może więc nie idzie o to, jacy są ludzie, ale do czego skłaniają ich okoliczności. Ten wątek przesuwa nas w stronę wpływu czynników sytuacyjnych na wrogość międzygrupową.

\section{Sytuacyjne mechanizmy wrogości międzygrupowej}

Dotychczas omówione koncepcje koncentrują się na czynnikach dyspozycyjnych, a więc takich, które związane są z cechami indywidualnymi. W psychologii polityki powszechny jest jednak pogląd, że agresja międzygrupowa, wrogość, dyskryminacja mogą być także efektem oddziaływań czynników sytuacyjnych. Debata nad nimi rozpoczęła się na dobre wraz z przedstawieniem przez Muzafera Sherifa teorii rzeczywistego konfliktu grupowego. Zgodnie z nią wrogość międzygrupowa jest konsekwencją rywalizacji o ograniczone dobro, zwycięstwo jednych jest zaś stratą drugich ${ }^{56}$, przy czym w zasadzie nie idzie tu wcale o sprzeczność jako taką, lecz o jej postrzeganie o psychologicznie doświadczaną potrzebę posiadania rzadkiego dobra ${ }^{57}$. Idea ta została potwierdzona w słynnym Robber's Cave Experiment, podczas którego najpierw stworzono tożsamości dwóch grup chłopców, następnie doprowadzono do pojawienia się postaw wrogich między nimi na podstawie rywalizacji o niepodzielne dobra, by następnie, testując hipotezę kontaktu Gordona Allporta, zmniejszyć ich poziom ${ }^{58}$. W efekcie potwierdzono, że jawna i wyraźna rywalizacja o rzadkie dobra prowadzi do wzrostu etnocentryzmu oraz spójności grupowej, a także uprzedzeń i negatywnych postaw wobec członków grupy obcej ${ }^{59}$.

Teoria Sherifa przedstawia konflikty społeczne w kategoriach uświadomionej sprzeczności interesów. Nie jest w związku z tym na gruncie tej koncepcji jasne, dlaczego stronniczość międzygrupowa może pojawić się nawet bez określonego przedmiotu sporu i dlaczego nie znika wówczas, gdy ów przedmiot rywalizacji przestaje istnieć ${ }^{60}$. Te problemy stały się punktem wyjścia dla bodaj najbardziej wpływowej teorii sytuacyjnych

$55 \mathrm{Na}$ ten temat zob. P. Zimbardo, Efekt Lucyfera. Dlaczego dobrzy ludzie czynia zło?, Warszawa 2008.

56 D. Abrams, Teoria realnego konfliktu, [w:] Encyklopedia Blackwella: psychologia społeczna, red. A.S.R. Manstead et al., Warszawa 1996, s. 652.

57 S.R. Khan, V. Samarina, Realistic Group Conflict Theory, [w:] Encyclopedia of Social Psychology, red. R.F. Baumeister, K.D. Vohs, Thousand Oaks, Calif. 2007, s. 725-726.

${ }_{58} \mathrm{M}$. Sherif et al., The Robbers Cave Experiment: Intergroup Conflict and Cooperation, Connecticut 1988, s. 24-62.

59 W.G. Stephan, C.W. Stephan, Wywieranie wpływu przez grupy. Psychologia relacji, Gdańsk 2003, s. $151-152$.

${ }^{60}$ R. Brown, Procesy grupowe. Dynamika wewnątrzgrupowa i międzygrupowa, Gdańsk 2006, s. 229; T.D. Nelson, op. cit., s. 85. 
mechanizmów wrogości międzygrupowej - wielokrotnie potwierdzanej w badaniach empirycznych, a także będącej podstawą wielu innych koncepcji. Teoria tożsamości społecznej (Social Identity Theory - SIT), bo o niej tutaj mowa, została zaproponowana przez Henriego Tajfela oraz Johna C. Turnera jako próba wyjaśnienia procesów grupowych. Jej punktem wyjścia jest zjawisko psychofizyczne zwane akcentuacją polegające na przecenianiu podobieństwa wewnątrz kategorii oraz przeszacowaniu różnic pomiędzy kategoriami. Okazuje się, że podobny mechanizm zachodzi w relacjach społecznych, prowadząc do spostrzegania spójności grupy własnej oraz jej odrębności od grupy obcej $^{61}$. Słynne eksperymenty przeprowadzone na początku lat 70 . XX w. przez Tajfela i współpracowników pozwoliły także na uznanie, iż procesy grupowe w postaci faworyzacji grupy własnej oraz dyskryminacji grupy obcej zachodzą już w paradygmacie grupy minimalnej, a więc wówczas, gdy badani znajdują się w sytuacji, w której nie zachodzi żaden wcześniejszy konflikt interesów, nie ma żadnej wcześniejszej sympatii lub antypatii grupowej ${ }^{62}$. Innymi słowy, do pojawienia się wrogości międzygrupowej wystarczy dowolna, nawet zupełnie nieistotna cecha, która umożliwi jednostkom skategoryzowanie siebie jako członków grupy, a przez to uruchomi wspomniane wyżej procesy. Sprzeczność interesów nie jest więc warunkiem koniecznym do pojawienia się wrogości międzygrupowej - jest nim kategoryzacja siebie jako członka grupy i pojawiające się wraz $z$ tym procesy faworyzacji grupy własnej i dyskryminacji grupy obcej ${ }^{63}$.

Zgodnie z SIT wszyscy ludzie wyposażeni są w hipotetyczną strukturę zwaną koncepcją-siebie, która składa się z dwóch części: tożsamości osobistej oraz tożsamości społecznej. Ta pierwsza zawiera wyobrażenie na temat „ja” wraz ze znaczeniem emocjonalnym, umożliwiając poczucie unikatowości, wyjątkowości, bycia innym od wszystkich ${ }^{64}$. Tym samym można uznać, że tożsamość osobista pojawia się na granicy między „ja” i „my”, podczas gdy pomiędzy „my” i „oni” pojawia się tożsamość społeczna ${ }^{65}$, którą Tajfel definiuje jako

element jednostkowego wyobrażenia samego siebie, wynikający z wiedzy jednostki o przynależności do grupy społecznej (lub grup), łącznie z przypisywanym temu członkostwu znaczeniem emocjonalnym ${ }^{66}$.

Innymi słowy, ma ona dwa wymiary: poznawczy i afektywny. Ten pierwszy związany jest z procesem kategoryzacji i określania siebie jako członka pewnych grup, ten

61 H. Tajfel, Social psychology of intergroup relations, „Annual Review of Psychology” 1982, nr 33, s. 21.

${ }^{62}$ H. Tajfel, J.C. Turner, An Integrative Theory of Intergroup Conflict, [w:] The Social Psychology of Intergroup Relations, red. W.G. Austin, S. Worchel, Monterey CA 1979, s. 38-39; H. Tajfel et al., Social categorization and intergroup behaviour, „European Journal of Social Psychology” 1971, nr 1 (2), s. 149-178; M. Billig, H. Tajfel, Social categorization and similarity in intergroup behaviour, „European Journal of Social Psychology" 1974, nr 3 (1), s. 27-52.

${ }^{63}$ H. Tajfel, J.C. Turner, op. cit., s. 38-40.

64 J.C. Turner, Towards a Cognitive Redefinition of the Social Group, [w:] Social Identity and Intergroup Relations, red. H. Tajfel, Cambridge 1982, s. 21; N. Ellemers, Social Identity Theory, [w:] Encyclopedia of Group Processes \& Intergroup Relations, red. J.M. Levine, M.A. Hogg, London 2010, s. 798.

65 M. Jarymowicz, Próba operacjonalizacji pojęć „tożsamość społeczna - tożsamość osobista”: odrębność schematowa Ja-My-Inni jako atrybut tożsamości, „Studia Psychologiczne” 1989, nr 27 (2), s. 74-75.

${ }^{66}$ H. Tajfel, Tożsamość społeczna a zachowanie międzygrupowe, „Przegląd Psychologiczny” 1976, nr 19 (2), s. 156. 
drugi zaś z emocjonalną wagą takiej przynależności. Ta ostatnia kwestia jest istotna o tyle, o ile uniwersalną cechą ludzi jest pragnienie wysokiej samooceny, a skoro tak, to poprzez identyfikację z różnymi „my” i porównania owych grup z innymi grupami jednostka osiąga pozytywną tożsamość społeczną i w konsekwencji również pozytywną koncepcję-siebie ${ }^{67}$.

Tożsamość osobista i tożsamość społeczna są antagonistyczne, co oznacza, że aktywacja jednej pociąga za sobą wygaszanie drugiej i odwrotnie ${ }^{68}$. W przypadku pojawienia się bodźców przypominających o przynależności grupowej (np. symbolika, wyrazistość fizyczna lub normatywna, duża liczba członków grupy obcej itp. ${ }^{69}$ ) aktywowana zostanie tożsamość społeczna, jednostka zacznie zaś funkcjonować zgodnie z jej standardami, niejako z pominięciem osobistych przekonań, cech indywidualnych, wyjątkowych atrybutów ${ }^{70}$. Co ważne, wraz z myśleniem przez pryzmat „my” pojawia się skłonność do zachowań zuniformizowanych, homogenicznych, niewielkie zróżnicowanie postaw wobec innych, którzy postrzegani są jako podobni sobie, czytelny podział ludzi wobec kategorii społecznych (studenci, robotnicy, przemysłowcy itp.) ${ }^{71}$.

O ile jednostka dąży do podtrzymania wysokiej samooceny, o tyle brak satysfakcji z przynależności grupowej prowadzi do podjęcia działań na rzecz zmiany tego stanu. Co za tym idzie, może, po pierwsze, starać się o zmianę swojej pozycji poprzez dołączenie do grupy o wyższej pozycji. Może także, po drugie, podjąć działania na rzecz poprawy położenia swojej grupy, czyniąc to albo poprzez zmianę wymiaru porównań (np. gdy nasza drużyna przegrywa mecz, można pocieszać się, że przegrała bohatersko i walczyła mężnie), albo poprzez zmianę wartości porównywanych cech (np. nasza drużyna przegrała mecz, ale w sumie nic się nie stało, „to tylko sport”), albo też przez porównanie z inną grupą (np. z „tymi” przegraliśmy, ale od „tamtych” jesteśmy lepsi). I wreszcie, po trzecie, może wejść w rzeczywisty konflikt, gdzie wyartykułowane i sprzeczne interesy przełożą się na realną walkę pomiędzy grupami ${ }^{72}$.

Jak już wspomniałem, najistotniejszą konsekwencją procesów grupowych jest pojawienie się faworyzacji grupy własnej i dyskryminacji grupy obcej, które są efektem czynników poznawczych (umieszczenia siebie w określonej kategorii społecznej, a więc przyjęcia pewnego „my”) oraz motywacyjnych (potrzeby wysokiej samooceny). Są to procesy automatyczne, które zachodzą poza świadomością podmiotu — podobnie jak efekty, które są z nimi związane ${ }^{73}$. Możliwy wachlarz działań społecznych z nich wynikających jest jednak bardzo szeroki. Faworyzacja grupy własnej i dyskryminacja grupy

${ }^{67}$ H. Tajfel, J.C. Turner, op. cit., s. 40.

68 J.C. Turner, Towards a Cognitive Redefinition of the Social Group..., s. 21.

69 A. Bikont, Tożsamość społeczna w świetle prac H. Tajfela i J.C. Turnera, „Przegląd Psychologiczny” 1986, nr 29 (3), s. 776.

${ }^{70}$ H. Tajfel, Tożsamość społeczna a zachowanie międzygrupowe..., s. 176.

71 A. Bikont, Tożsamość społeczna - teorie, hipotezy, znaki zapytania, [w:] Studia nad spostrzeganiem relacji „Ja-Inni”: tożsamość, indywiduacja, przynależność, red. M. Jarymowicz, Warszawa 1998, s. 25-30.

${ }^{72}$ H. Tajfel, J.C. Turner, op. cit., s. 43-44.

${ }^{73}$ H. Tajfel, J.C. Turner, The Social Identity Theory of Intergroup Behavior, [w:] Psychology of Intergroup Relations, red. S. Worchel, L.W. Austin, Chicago 1986, s. 13. 
obcej obejmują bowiem działania subtelne, gdy „swoim” chętniej pomagam, częściej się do nich uśmiecham czy zwyczajnie cieplej o nich myślę, podczas gdy o „obcych” myślę mniej ciepło i wcale do pomocy się nie palę; jak również działania bardziej wyraźne, gdy "swoich” wprost chwalę i wywyższam, „obcym” zaś odmawiam prawa do zajmowania stanowiska, a nawet pozostawania w pewnej przestrzeni społecznej; aż po jawne przypadki radykalnej i ekstremalnej wrogości zmierzającej do usunięcia „wrogów”, odmowy im prawa do istnienia, ich zniszczenia, eksterminacji. Na początku mamy więc nieinstrumentalne środki negatywne w postaci stereotypów i uprzedzeń, a na końcu otwartą walkę przy użyciu pełnego instrumentarium środków przemocy symbolicznej i fizycz$n j^{74}$. Co ważne, przejście od depersonalizacji (swego rodzaju wtopienia „ja” w „my), przez infrahumanizację, aż po dehumanizację nie oznacza wcale zmiany jakościowej - to raczej różnica stopnia, a nie nowe zjawiska. W konsekwencji więc wrogość międzygrupowa nie jest wcale zjawiskiem rzadkim i wyjątkowym, lecz jest ona powszechnie występującą $\mathrm{w}$ relacjach społecznych reakcją związaną z przyjęciem określonej tożsamości społecznej, która automatycznie powołuje do życia zjawiska faworyzacji grupy własnej i dyskryminacji grupy obcej.

Wypada wspomnieć, że teoria tożsamości społecznej została przeformułowana pod koniec lat 80 . XX w. przez Johna C. Turnera i współpracowników, stając się podstawą teorii autokategoryzacji (Self-Categorization Theory) ${ }^{75}$. Nie ma potrzeby omawiać jej tutaj szczegółowo. Dość powiedzieć, że tak teoria tożsamości społecznej, jak teoria autokategoryzacji tworzą razem podejście tożsamości społecznej (Social Identity Approach) ${ }^{76}$, które okazało się niezwykle inspirujące dla bardzo wielu teorii wyjaśniających sytuacyjne mechanizmy konfliktów i wrogości. W tym artykule skupię się tylko na jednej z nich, która bodaj najwyraźniej stara się dopełnić twierdzenia SIT. Idzie tu o teorię uzasadnia systemu (System Justification Theory - SJT), zaproponowaną przez Johna T. Josta i Mahzarin Banaji. U jej podstaw leży ten sam problem, który zainteresował Tajfela i Turnera, tj. dlaczego rywalizacja nie zawsze prowadzi do otwartego konfliktu. Zgodnie z SIT znalezienie się w sytuacji, w której jednostka nie jest w stanie zaspokoić potrzeby wysokiej samooceny, pchnie ją w kierunku działań na rzecz poprawy swojego losu. Idąc tym tropem, można uznać, że świat powinien składać się wyłącznie $\mathrm{z}$ aktualnych lub potencjalnych rewolucjonistów - tak jednak się nie dzieje. Wielu ludzi jest gotowych podtrzymywać systemy społeczne nawet, gdy są dla nich krzywdzące ${ }^{77}$. Innymi słowy,

74 Ibidem, s. 24.

75 Zob. np.: J.C. Turner et al., Rediscovering the Social Group. A Self-Categorization Theory, Oxford 1987; J.C. Turner, Teoria autokategoryzacji, [w:] Encyklopedia Blackwella..., s. 632; M. Jarymowicz, Psychologia tożsamości, [w:] Psychologia: podręcznik akademicki, red. J. Strelau, t. 3, Gdańsk 2000.

76 Zob. np.: D. Abrams, M.A. Hogg, Metatheory: Lessons from social identity research, „Personality and Social Psychology Review” 2004, nr 8 (2), s. 100; M.A. Hogg, D. Abrams, Social Identifications: A Social Psychology of Intergroup Relations and Group Processes, London 1988, s. 15; M.J. Hornsey, Social identity theory and self-categorization theory: A historical review, „Social and Personality Psychology Compass” 2008, nr 2/1, s. 204-218.

77 J.T. Jost, System Justification Theory, [w:] Encyclopedia of Group Processes \& Intergroup Relations..., s. 888 . 
SJT próbuje wyjaśnić, jak możliwe jest paradoksalne zjawisko faworyzacji grupy obcej zamiast własnej ${ }^{78}$.

Warto nadmienić, że przez „system” rozumie się w SJT każdą możliwą społeczną, ekonomiczną lub polityczną formę zorganizowania ${ }^{79}$, jego uzasadnianie odnosi się zaś do psychologicznego procesu uprawomocniania istniejących w nim struktur i relacji społecznych oraz spostrzegania ich jako sprawiedliwych i słusznych ${ }^{80}$.

Uzasadnianie systemu motywowane jest w trojaki sposób: po pierwsze, uzasadnienie osobiste odwołuje się do wysokiej samooceny, gdzie użycie uprzedzeń i stereotypów ma na celu ochronę pozycji jednostki; drugim jest uzasadnienie grupowe odnoszące się do tożsamości grupowej i służące ochronie jej interesów. Uzasadnienie systemu, jako trzecia forma, jest o tyle odmienne, że uprzedzenia i stereotypy nie chronią tu ani jednostki, ani grupy, lecz względnie stabilne i trwałe struktury społeczne, nierzadko krzywdzące dla tych, którzy stają w ich obronie ${ }^{81}$. Co za tym idzie, stereotypy uzasadniające system są na dobrą sprawę formą fałszywej świadomości, o czym sami autorzy zaświadczają ${ }^{82}$.

Według SJT ludzie mają tendencję do racjonalizacji status quo, która nasila się w sytuacji zagrożenia. Ze względu na fakt, że ochrona istniejącego porządku odnosi się tak do grup uprzywilejowanych, jak grup upośledzonych, w obu obserwuje się zjawiska faworyzacji grupowej, przy czym w przypadku pierwszym to faworyzacja grupy własnej, a w drugim — obcej, co oznacza, że słabsi i podporządkowani w imię status quo są skłonni do popierania silniejszych. Przejawia się to m.in. w przekonaniu członków grupy podporządkowanej o posiadaniu mniejszych praw grupy własnej od członków grupy dominującej. Więcej jeszcze, podporządkowani nierzadko bronią systemu silniej od panujących ${ }^{83}$.

Jak już wspominałem, uzasadnianie systemu dokonuje się najczęściej za sprawą stereotypów. Wyróżnić tu można dwa ich rodzaje: po pierwsze, do uzasadniania niższej pozycji grupy podporządkowanej przez jej członków służą stereotypy komplementarne, a więc takie, które w istocie kompensują braki i niedoskonałości. Przykładem są tu powiedzenia, takie jak „biedny, ale szczęśliwy”, „przegrany, ale honorowy” itp. Stereotypy tego rodzaju zniechęcają do buntu i zmiany status quo. Po drugie, do uzasadniania niższej pozycji grupy podporządkowanej przez członków grupy dominującej wykorzystuje się stereotypy niekomplementarne, które podkreślają odpowiedzialność słabszych za ich los, tak jak dzieje się to, gdy „rozgrzesza się” gwałciciela, zrzucając odpowiedzialność na „prowokujący" ubiór lub zachowanie ofiary ${ }^{84}$.

78 J.T. Jost, M.R. Banaji, The role of stereotyping in system-justification and the production of false consciousness, „British Journal of Social Psychology” 1994, nr 33, s. 7-8.

$79 \mathrm{~J}$. van der Toorn, J.T. Jost, Twenty years of system justification theory: Introduction to the special issue on "Ideology and system justification processes”, „Group Processes \& Intergroup Relations” 2014, nr 17 (4), s. 413-414.

80 J.T. Jost, M.R. Banaji, op. cit., s. 2-3; M. Kossowska, O motywach sprzyjających..., s. 16.

81 J.T. Jost, M.R. Banaji, B.A. Nosek, A decade of system justification theory: Accumulated evidence of conscious and unconscious bolstering of the status quo, „Political Psychology” 2004, nr 25 (6), s. 887-889.

82 J.T. Jost, M.R. Banaji, op. cit., s. 3 oraz 17.

83 J.T. Jost, M.R. Banaji, B.A. Nosek, op. cit., s. 889-911.

84 G. Blasi, J.T. Jost, System justification theory and research: Implications for law, legal advocacy, and social justice, „California Law Review” 2006, nr 94 (4), s. 1134-1135. 
Konkludując, można oddać głos Jostowi i współpracownikom, według których

w przeciwieństwie do innych teorii, teoria uzasadniania systemu jednoznacznie postuluje, że: (a) istnieje ideologiczny motyw, by uzasadniać istniejący porządek społeczny, (b) ów motyw odpowiedzialny jest, przynajmniej w części, za faworyzację grupy obcej oraz internalizację poczucia niższości pośród członków grup podporządkowanych, (c) daje się to zaobserwować szczególnie łatwo na utajonym i nieświadomym poziomie oraz (d) paradoksalnie, kwestie są nawet silniejsze pośród najbardziej upośledzonych grup społecznych ${ }^{85}$.

I znów, podobnie jak w przypadku teorii dyspozycyjnych, można by tu wspomnieć o wielu innych koncepcjach sytuacyjnych, by wyliczyć choćby teorię opanowywania $\operatorname{trwogi}^{86}$, teorię kolektywnego narcyzmu ${ }^{87}$, teorię infrahumanizacji ${ }^{88}$ czy teorię dehumanizacji ${ }^{89}$. Nie zmieniłoby to jednak zasadniczego przekonania płynącego z powyższych rozważań, a mianowicie, że skłonność do wrogości międzygrupowej jest nie tyle cechą indywidualną, ile pojawia się sytuacyjnie, najczęściej jako odpowiedź na różnego rodzaju zagrożenia, w szczególności tożsamości, pozycji społecznej i statusu, wartości i norm. Ten obraz jednak dalej wydaje się niepełny. Dlaczego bowiem to mężczyźni są bardziej skłonni do agresji, przemocy, postaw wrogich wobec innych? Dlaczego to mężczyźni zawiązują najczęściej koalicje wojenne? Czy należy wyjaśniać to wyłącznie wpływem kultury, czy może warto pamiętać, że jako zwierzę człowiek jest także produktem ewolucji. Kwestie te warto także poruszyć.

\section{Poza czynnikami dyspozycyjnymi i sytuacyjnymi — ewolucyjne podstawy konfliktów społecznych i wrogości}

Nie wolno zapominać, że dyspozycyjne i sytuacyjne czynniki wrogości międzygrupowej nie są jedynymi determinantami, które powinny być brane pod uwagę w rozważaniach nad powstawaniem, podtrzymywaniem i eskalacją konfliktów społeczno-politycznych. Wielką rolę odgrywają tu bowiem także mechanizmy ukształtowane w toku ewolucji.

Trzeba odnotować, że w ostatnich dwóch dziesięcioleciach w naukach społecznych rozgrywa się swego rodzaju rewolucja polegająca na ponownym włączaniu do wyjaśnień zachowań społecznych i działań ludzkich koncepcji pojawiających się na styku między tym, co społeczne, i tym, co biologiczne. Oczywiście rzecz nie jest nowa - biologiczne determinanty świata społecznego były znacznie wcześniej wskazywane, owocując

85 J.T. Jost, M.R. Banaji, B.A. Nosek, op. cit., s. 912.

$86 \mathrm{Na}$ ten temat zob.: T. Pyszczynski, S. Solomon, J. Greenberg, In the Wake of 9/11. The Psychology of Terror, Washington DC 2010; T. Pyszczynski, What are we so afraid of? A terror management theory perspective on the politics of fear, „Social Research” 2004, nr 71 (4); Teoria opanowywania trwogi. Dyskurs w literaturze amerykańskiej, red. M. Rusaczyk, Warszawa 2008.

$87 \mathrm{Na}$ ten temat zob. A. Cichocka, A. Golec de Zavala, Kolektywny narcyzm a sprawa polska, [w:] Wobec obcych..., s. 232-247.

$88 \mathrm{Na}$ ten temat zob. J.-P. Leyens et al., The emotional side of prejudice: The attribution of secondary emotions to ingroups and outgroups, „Personality and Social Psychology Review” 2000, nr 4 (2).

89 Na ten temat zob.: N. Haslam, Dehumanization: An integrative review, „Personality and Social Psychology Review” 2006, nr 10 (3); idem et al., Spojrzenie na dehumanizacje, [w:] Poza stereotypy. Dehumanizacja i esencjalizm w postrzeganiu grup społecznych, red. M. Drogosz, M. Bilewicz, M. Kofta, Warszawa 2012. 
ideami o dramatycznych skutkach w postaci rasizmu i eugeniki. Można nawet powiedzieć, że kariera wyjaśnień ewolucyjnych była równie spektakularna, jak efektowny był ich upadek, gdy refleksja nad ich amoralnymi konsekwencjami stała się powszechna po drugiej wojnie światowej. Nie oznacza to jednak, że poszukiwanie biologicznych determinantów świata społecznego zostało zaniechane. Więcej jeszcze, w ostatnich dekadach obszar ten rozwija się niezwykle dynamicznie, ale nie idzie już tu o wzmiankowane wyżej „determinanty” - idzie o „preferencje”, o „prawdopodobieństwo”. Tym właśnie, przede wszystkim, różni się nowy ewolucjonizm od starego ewolucjonizmu (szczególnie w psychologii), że uznaje, iż genotyp, a więc skład genowy organizmu, nie determinuje, lecz jedynie uwarunkowuje fenotyp, czyli cechy ujawniane społecznie. Innymi słowy, nowy ewolucjonizm w psychologii przyjmuje, że działania jednostki są wypadkową elementów biologicznych i społecznych, a kultura i geny współpracują z sobą, przy czym rola tej pierwszej jest olbrzymia ${ }^{90}$.

Idąc za Davidem Bussem, można powiedzieć, że nowy ewolucjonizm wspiera się na pięciu sądach: pierwszy już został podany i oznacza, że dziedziczenie predyspozycji do zachowań pewnego rodzaju nie oznacza dziedziczenia owych zachowań, co zawiera się w przekonaniu, iż geny i kultura uzupełniają się i współdziałają, a nie, że te pierwsze poprzedzają tę drugą; po drugie, ukształtowane ewolucyjnie cechy mogą ulegać zmianie pod wpływem socjalizacji i kulturalizacji; po trzecie, dobór drogą dostosowania łącznego jest możliwy i nie wymaga wcale wielkich umiejętności „matematycznych” celem określania stopnia pokrewieństwa; po czwarte, ze względu na tempo i swego rodzaju niedoskonałość mechanizmów ewolucyjnych wiele adaptacji jest dalece niedoskonałych (na marginesie można dodać, że jest to jeden ze sposobów wyjaśniania podłoża zaburzeń osobowości); po piąte, uznanie biologicznych fundamentów życia społecznego, lecz postrzeganie ich jako zmiennych i zależnych kulturowo, pozwala uniknąć wulgarnej redukcji świata społecznego do potrzeb reprodukcyjnych ${ }^{91}$.

Pole zainteresowań nowego ewolucjonizmu jest bardzo rozległe: począwszy od atrakcyjności fizycznej, dojrzewania, empatii, inteligencji, poprzez patologie społeczne, organizacje społeczne, język, konflikty rodzicielskie, kulturę, postawy, motywacje, normy społeczne, przywództwo, zachowania społeczne, rasizm, wierzenia religijne, aż po obraz siebie, podejmowanie decyzji, różnice indywidualne i osobowość, mechanizmy poznaw$\mathrm{cze}^{92}$. Pozwala to widzieć w nowym ewolucjonizmie, zwłaszcza na polu psychologii, płaszczyznę łączenia rozmaitych podejść badawczych i teorii ${ }^{93}$.

${ }^{90}$ R. Bloom, The Evolution of Scientific Psychology and Public Policy. On Violence and Its Antidotes, [w:] Evolutionary Psychology and Violence. A Primer for Policymakers and Public Policy Advocates, red. R.W. Bloom, N. Dess, London 2003, s. 12.

91 D.M. Buss, Psychologia ewolucyjna, Gdańsk 2001, s. 40-44.

92 Ł. Budzicz, Znaczenie myślenia ewolucyjnego we wspótczesnej psychologii, „Nauka” 2012, nr 3, s. 96-100; zob. także: Oxford Handbook of Evolutionary Psychology, red. L. Barrett, R. Dunbar, Oxford 2007.

93 D.M. Buss, Evolutionary psychology: A new paradigm for psychological science, „Psychological Inquiry" 1995, nr 6 (1), s. 1-2. 
Żelaznymi tematami nowego ewolucjonizmu są także agresja, przemoc i wojna ${ }^{94}$. John Tooby i Leda Cosmides bodaj jako pierwsi zaproponowali ewolucyjną teorię wojny, wskazując, że pojawianie się agresywnych koalicji jest możliwe, gdy zyski reprodukcyjne są zasadniczo wyższe od potencjalnych kosztów konfliktu, ryzyko przekłada się na zyski, a śmierć nie jest pewna ${ }^{95}$. Pierwotnie koalicje wojenne powstawały w celu zwiększenia szans reprodukcyjnych, przy czym idzie tu o szanse grupowe, a nie indywidualne. Działania wojenne są tu bowiem widziane z perspektywy lojalności grupowej, gdzie od indywidualnej egzystencji ważniejsze staje się przetrwanie grupy własnej i osłabienie grupy obcej ${ }^{96}$. Przedstawiając własne ujęcie problemu, Buss następująco puentuje te kwestie:

(1) mechanizmy psychiczne skłaniające do zawiązywania koalicji wojennych rozwiną się u mężczyzn, ale nie u kobiet; (2) główną korzyścią z przystąpienia do koalicji jest dla mężczyzny zwiększony dostęp seksualny do kobiet; (3) u mężczyzn powinny się wykształcić mechanizmy psychiczne skłaniające do wystąpienia z koalicji i ucieczki z pola walki, jeśli w razie pozostania śmierć wydaje się pewna; (4) mężczyźni powinni iść na wojnę tym chętniej, im większe są szanse na zwycięstwo [...]; (5) u mężczyzn powinny wykształcić się mechanizmy służące egzekwowaniu umowy koalicyjnej - to jest wykrywaniu i karaniu oszustów, zdrajców i dezerterów; (6) u mężczyzn powinny się też wykształcić mechanizmy wyszukiwania, pozyskiwania i wyróżniania lojalnych sprzymierzeńców ${ }^{97}$.

Innymi słowy, konflikty leżą w „ludzkiej naturze”, zwłaszcza zaś w „naturze” męskiej. Jej stałym elementem jest gotowość do walki o zasoby, władzę, terytorium, grupę własną i wiele innych kwestii ${ }^{98}$.

Jeśli agresja jest wytworem ewolucyjnych procesów, to podobnie będzie z jej radykalną odmianą - zabijaniem. Buss wprost powiada, że człowiek musiał zmierzyć się $\mathrm{w}$ toku ewolucji z problemem zabijania innych ludzi i na dobrą sprawę przystosował się do tego ${ }^{99}$. Więcej jeszcze, biorąc pod uwagę - choć brzmi to wielce kontrowersyjnie korzyści, jakie płyną z zabijania, takie jak eliminacja rywali, zdobycie zasobów, ochrona przed śmiercią ze stronny innych, zasadniczym pytaniem nie jest to, dlaczego ludzie zabijają, ale dlaczego czynią to tak rzadko. Buss razem z Joshuą Duntleyem rozwiązują tę zagadkę poprzez przywołanie mechanizmu antagonistycznej koewolucji polegającego na stopniowym wykształcaniu coraz lepszych adaptacji ochronnych przez ofiary pod wpływem coraz lepszych zdolności drapieżników. Co za tym idzie, jak powiadają psy-

94 R.H. Blank, Brain Science and Politics: Some Linkages, [w:] Biology and Political Behavior: The Cutting Edge, red. S.A. Peterson, A. Somit, Bingley 2011, s. 214-220.

95 J. Tooby, L. Cosmides, The evolution of war and its cognitive foundations, „Institute for Evolutionary Studies Technical Report 88-1" 1988, s. 5-7, http://www.cep.ucsb.edu/papers/EvolutionofWar.pdf (dostęp: 6 stycznia 2017); D.M. Buss, Psychologia ewolucyjna..., s. 328.

96 J.R. Alford, J.R. Hibbing, The origin of politics: An evolutionary theory of political behavior, „Perspective on Politics" 2004, nr 2 (4), s. 712.

97 D.M. Buss, Psychologia ewolucyjna..., s. 329.

98 A. Gat, So why do people fight? Evolutionary theory and the causes of war, „European Journal of International Relations" 2009, nr 15 (4), s. 582-584.

99 D.M. Buss, Morderca za ścianą. Zabójcze skłonności ludzkiego umysłu, Sopot 2014, s. 18. 
cholodzy, wszyscy ludzie są wyposażeni w mechanizmy umożliwiające im popełnienie morderstwa, ale atakują bardzo rzadko w obawie przed własną śmiercią w walce ${ }^{100}$.

$\mathrm{Na}$ zakończenie warto dodać, że biologiczne podstawy konfliktów były wielokrotnie potwierdzane $\mathrm{w}$ badaniach empirycznych ${ }^{101}$. Niektóre $\mathrm{z}$ nich prowadziły do wniosków niezwykle ciekawych, jak choćby te uzyskane przez Santoshiego Kanazawę, który wykazał, że występowanie poligamii skutkującej ograniczeniem reprodukcji młodych mężczyzn jest silniej związane z wojnami domowymi aniżeli brak demokratycznych reguł ${ }^{102}$.

\section{Podsumowanie}

Celem tego artykułu było przedstawienie psychologicznych mechanizmów leżących u podstaw konfliktów społeczno-politycznych, które zostały zinterpretowane jako wrogość międzygrupowa obejmująca stereotypy, uprzedzenia i dyskryminację. Idąc dalej, czynniki wrogości międzygrupowej zostały podzielone na dwa rodzaje: dyspozycyjne, a więc takie, które są cechą jednostki, oraz sytuacyjne, a więc związane $\mathrm{z}$ otoczeniem, bodźcami, okolicznościami działania. Jak się okazuje, dyskryminacja, uprzedzenia i stereotypy pojawiają się w większym nasileniu u osób wysoko autorytarnych, osób o wysokiej orientacji na dominację społeczną, a także pod wpływem czynników zewnętrznych, głównie różnego rodzaju zagrożeń. To one umożliwiają nie tylko eskalację konfliktów, ale są także ważne dla ich pojawiania się oraz podtrzymywania nawet wówczas, gdy realny przedmiot sporu zniknął. Siła ich oddziaływania jest olbrzymia i nierzadko - jak w przypadku mechanizmów kategoryzacji leżących u podłoża dyskryminacji grupy obcej i faworyzacji grupy własnej — znajduje się poza świadomością jednostki.

Na zakończenie nie można jeszcze nie wspomnieć o sposobach redukcji wrogości międzygrupowej i agresji. Bez wątpienia najważniejszą w tym względzie koncepcją pozostaje - pomimo upływu ponad 60 lat od daty jej ogłoszenia - hipoteza kontaktu przedstawiona przez Gordona Allporta ${ }^{103}$. Opiera się ona, jak powiada Miles Hewstone, „na prostej idei, że zetknięcie się przedstawicieli różnych grup powinno poprawić ich wzajemne relacje"104. Była wielokrotnie testowana i można ją uznać bez większych kontrowersji za doskonale uzasadnioną empirycznie ${ }^{105}$. Skuteczność kontaktu wymaga według Allporta spełnienia czterech warunków, tj.: równego statusu interakcji, wspól-

100 D. Buss, J.D. Duntley, Homicide. An Evolutionary Psychological Perspective and Implications for Public Policy, [w:] Evolutionary Psychology and Violence..., s. 122-126.

101 Zob. np. D.M. Buss, Psychologia ewolucyjna..., s. 329-332.

102 S. Kanazawa, Evolutionary psychological foundations of civil war, „The Journal of Politics” 2009, nr 71 (1), s. 32 .

103 G. Allport, Nature of Prejudice, Doubleday-Anchor 1954.

104 M. Hewstone, Kontakt $i$ kategoryzacja: zmiana stosunków międzygrupowych w ujęciu psychologii społecznej, [w:] Stereotypy i uprzedzenia. Najnowsze ujęcie, red. C.N. Macrea, Ch. Stangor, M. Hewstone, Gdańsk 1999, s. 267.

105 Na ten temat zob. np.: R. Brown, Prejudice..., s. 243-280; idem, Procesy grupowe..., s. 298-301; T.D. Nelson, op. cit., s. 311-312; W.G. Stephan, C.W. Stephan, op. cit., s. 70-98. 
nych celów, współpracy międzygrupowej oraz wsparcia ze strony uznanych autorytetów. Yehuda Amir uzupełnił tę listę o kolejne dwa elementy: klimat sprzyjający kontaktom międzygrupowym oraz osobisty charakter interakcji ${ }^{106}$. Wraz z ich spełnieniem rośnie prawdopodobieństwo spadku wzajemnej niechęci i uprzedzeń oraz zmniejszenia się liczby zachowań dyskryminacyjnych, o czym warto pamiętać.

\section{Bibliografia}

Abrams D., Teoria realnego konfliktu, [w:] Encyklopedia Blackwella: psychologia społeczna, red. A.S.R. Manstead et al., Wydawnictwo Jacek Santorski \& CO, Warszawa 1996.

Abrams D., Hogg M.A., Metatheory: Lessons from social identity research, „Personality and Social Psychology Review" 2004, nr 8 (2).

Adamus-Matuszyńska A., Współczesne teorie konfliktu społecznego, Akademia Ekonomiczna im. Karola Adamieckiego, Katowice 1998.

Adorno T.W., Osobowość autorytarna, Wydawnictwo Naukowe PWN, Warszawa 2010.

Advances in Experimental Psychology, t. 33, red. M. Zanna, Academic Press, New York 2001.

Alford J.R., Hibbing J.R., The origin of politics: An evolutionary theory of political behavior, „Perspective on Politics" 2004, nr 2 (4).

Allport G., Nature of Prejudice, Garden City, Doubleday-Anchor 1954.

Altemeyer B., The Authoritarian Specter, Harvard University Press, London 1996.

Altemeyer B., The Authoritarians, University of Manitoba, Winnipeg 2006, http://members.shaw.ca/jeanaltemeyer/drbob/TheAuthoritarians.pdf (dostęp: 6 stycznia 2017).

Altemeyer B., The Other „Authoritarian Personality”, [w:] Political Psychology. Key Readings, red. J.T. Jost, J. Sidanius, Psychology Press, New York-Hove 2004.

Altemeyer B., What happens when authoritarians inherit the earth? A simulation, „Analyses of Social Issues and Public Policy" 2003, nr 3 (1).

Baars J., Scheepers P., Theoretical and methodological foundations of the authoritarian personality, „Journal of the History of the Behavioral Science" 1993, nr 29.

Baszkiewicz J., Władza, Zakład Narodowy im. Ossolińskich, Wrocław 1999.

Beyme K. von, Wspótczesne teorie polityczne, Wydawnictwo Naukowe Scholar, Warszawa 2005.

Białyszewski H., Teoretyczne problemy sprzeczności i konfliktów społecznych, Państwowe Wydawnictwo Naukowe, Warszawa 1983.

Bikont A., Tożsamość społeczna - teorie, hipotezy, znaki zapytania, [w:] Studia nad spostrzeganiem relacji „Ja-Inni”: tożsamość, indywiduacja, przynależność, red. M. Jarymowicz, Wydawnictwo Polskiej Akademii Nauk, Warszawa 1998.

Bikont A., Tożsamość społeczna w świetle prac H. Tajfela i J.C. Turnera, „Przegląd Psychologiczny” 1986, nr 29 (3).

Billig M., Tajfel H., Social categorization and similarity in intergroup behaviour, „European Journal of Social Psychology" 1974, nr 3 (1).

Biology and Political Behavior: The Cutting Edge, red. S.A. Peterson, A. Somit, Emerald Group Publishing Ltd., Bingley 2011.

Blank R.H., Brain Science and Politics: Some Linkages, [w:] Biology and Political Behavior: The Cutting Edge, red. S.A. Peterson, A. Somit, Bingley 2011.

Blasi G., Jost J.T., System justification theory and research: Implications for law, legal advocacy, and social justice, „California Law Review” 2006, nr 94 (4).

106 T.D. Nelson, op. cit., s. 311. 
Bloom R., The Evolution of Scientific Psychology and Public Policy. On Violence and Its Antidotes, [w:] Evolutionary Psychology and Violence. A Primer for Policymakers and Public Policy Advocates, red. R.W. Bloom, N. Dess, Praeger Publishers, London 2003.

Böhner B., Wänke M., Postawy i zmiana postaw, Gdańskie Wydawnictwo Psychologiczne, Gdańsk 2004.

Brown R., Prejudice: It's Social Psychology, Wiley-Blackwell, Oxford 2010.

Brown R., Procesy grupowe. Dynamika wewnątrzgrupowa i międzygrupowa, Gdańskie Wydawnictwo Psychologiczne, Gdańsk 2006.

Budzicz Ł., Znaczenie myślenia ewolucyjnego we współczesnej psychologii, „Nauka” 2012, nr 3.

Buss D.M., Evolutionary psychology: A new paradigm for psychological science, „Psychological Inquiry” 1995, nr 6 (1).

Buss D.M., Morderca za ścianą. Zabójcze skłonności ludzkiego umysłu, Gdańskie Wydawnictwo Psychologiczne, Sopot 2014.

Buss D.M., Psychologia ewolucyjna, Gdańskie Wydawnictwo Psychologiczne, Gdańsk 2001.

Buss D., Duntley J.D., Homicide. An Evolutionary Psychological Perspective and Implications for Public Policy, [w:] Evolutionary Psychology and Violence. A Primer for Policymakers and Public Policy Advocates, red. R.W. Bloom, N. Dess, Praeger Publishers, London 2003.

Cichocka A., Golec de Zavala A., Kolektywny narcyzm a sprawa polska, [w:] Wobec obcych. Zagrożenia psychologiczne a stosunki międzygrupowe, red. M. Kofta, M. Bilewicz, Wydawnictwo Naukowe PWN, Warszawa 2011.

Coser L.A., Funkcje konfliktu społecznego, Zakład Wydawniczy „Nomos”, Kraków 2009.

Costello K., Hodson G., Social dominance-based threat reactions to immigrants in need of assistance, „European Journal of Social Psychology" 2011, nr 41.

Czajowski A., Władza polityczna. Analiza pojęcia, [w:] Studia z teorii polityki, red. A.W. Jabłoński, L. Sobkowiak, t. 1, Wydawnictwo Uniwersytetu Wrocławskiego, Wrocław 1996.

Dahl R.A., Stinebrickner B., Współczesna analiza polityczna, Wydawnictwo Naukowe Scholar, Warszawa 2007.

Dahrendorf R., Klasy i konflikt klasowy w społeczeństwie przemysłowym, Zakład Wydawniczy „Nomos”, Kraków 2008.

Dahrendorf R., Nowoczesny konflikt społeczny: esej o polityce wolności, Czytelnik, Warszawa 1993.

Dovidio J.F. et al., Prejudice, Stereotyping and Discrimination: Theoretical and Empirical Overview, [w:] The Sage Handbook of Prejudice, Stereotyping and Discrimination, red. idem et al., Sage Publications Ltd., London 2013.

Duckitt J., Authoritarianism and group identification: A new view of an old construct, „Political Psychology” 1989, nr 10 (1).

Duckitt J., A Dual-Process Cognitive-Motivational Theory of Ideology and Prejudice, [w:] Advances in Experimental Psychology, t. 33, red. M. Zanna, Academic Press, New York 2001.

Duckitt J., Uprzedzenia i wrogość między grupami, [w:] Psychologia polityczna, red. D.O. Sears, L. Huddy, R. Jervis, Wydawnictwo Uniwersytetu Jagiellońskiego, Kraków 2008.

Ellemers N., Social Identity Theory, [w:] Encyclopedia of Group Processes \& Intergroup Relations, red. J.M. Levine, M.A. Hogg, Sage Publications Ltd., London 2010.

Encyclopedia of Group Processes \& Intergroup Relations, red. J.M. Levine, M.A. Hogg, Sage Publications Ltd., London 2010.

Encyclopedia of Social Psychology, red. R.F. Baumeister, K.D. Vohs, Sage Publications Inc., Thousand Oaks, Calif. 2007.

Encyklopedia Blackwella: psychologia społeczna, red. A.S.R. Manstead et al., Wydawnictwo Jacek Santorski \& CO, Warszawa 1996.

Evolutionary Psychology and Violence. A Primer for Policymakers and Public Policy Advocates, red. R.W. Bloom, N. Dess, Praeger Publishers, London 2003.

Eysenck H.J., The Psychology of Politics, Transaction Publishers, New Brunswick-London 1999.

Frenkel-Brunswick F., Intolerance of ambiguity as an emotional and perceptual personality variable, „Journal of Personality" 1949, nr 18 (1). 
Fromm E., Anatomia ludzkiej destrukcyjności, Dom Wydawniczy Rebis, Poznań 1999.

Fromm E., Mieć czy być?, Dom Wydawniczy Rebis, Poznań 2000.

Fromm E., Ucieczka od wolności, Czytelnik, Warszawa 2008.

Gat A., So why do people fight? Evolutionary theory and the causes of war, „European Journal of International Relations" 2009, nr 15 (4).

Grzesiak-Feldman M., Psychologia myślenia grupowego, Wydawnictwo Uniwersytetu Warszawskiego, Warszawa 2016.

Handbook of Theories of Social Psychology, red. P.A.M. van Lange, A.W. Kruglanski, E.T. Higgins, t. 2, Sage Publications Ltd., London 2012.

Haslam N., Dehumanization: An integrative review, „Personality and Social Psychology Review” 2006, nr $10(3)$.

Haslam N. et al., Spojrzenie na dehumanizacje, [w:] Poza stereotypy. Dehumanizacja i esencjalizm w postrzeganiu grup społecznych, red. M. Drogosz, M. Bilewicz, M. Kofta, Wydawnictwo Naukowe Scholar, Warszawa 2012.

Held D., Introduction to Critical Theory. Horkheimer to Habermas, University of California Press, Berkeley-Los Angeles 1980.

Herbut R., Interes polityczny jako kategoria politologiczna, [w:] Studia z teorii polityki, red. A.W. Jabłoński, L. Sobkowiak, t. 1, Wydawnictwo Uniwersytetu Wrocławskiego, Wrocław 1996.

Hewstone M., Kontakt i kategoryzacja: zmiana stosunków międzygrupowych w ujęciu psychologii społecznej, [w:] Stereotypy i uprzedzenia. Najnowsze ujęcie, red. C.N. Macrea, Ch. Stangor, M. Hewstone, Gdańskie Wydawnictwo Psychologiczne, Gdańsk 1999.

Hogg M.A., Abrams D., Social Identifications: A Social Psychology of Intergroup Relations and Group Processes, Routledge, London 1988.

Hornsey M.J., Social identity theory and self-categorization theory: A historical review, „Social and Personality Psychology Compass" 2008, nr 2/1.

Jakubowska U., Ekstremizm polityczny. Studium psychologiczne, Gdańskie Wydawnictwo Psychologiczne, Gdańsk 2005.

Jarymowicz M., Próba operacjonalizacji pojęć „tożsamość społeczna - tożsamość osobista”: odrębność schematowa Ja-My-Inni jako atrybut tożsamości, „Studia Psychologiczne” 1989, nr 27 (2).

Jarymowicz M., Psychologia tożsamości, [w:] Psychologia: podręcznik akademicki, red. J. Strelau, t. 3, Gdańskie Wydawnictwo Psychologiczne, Gdańsk 2000.

Jost J.T., System Justification Theory, [w:] Encyclopedia of Group Processes \& Intergroup Relations, red. J.M. Levine, M.A. Hogg, Sage Publications Ltd., London 2010.

Jost J.T., Banaji M.R., The role of stereotyping in system-justification and the production of false consciousness, „British Journal of Social Psychology” 1994, nr 33.

Jost J.T., Banaji M.R., Nosek B.A., A decade of system justification theory: Accumulated evidence of conscious and unconscious bolstering of the status quo, „Political Psychology” 2004, nr 25 (6).

Kaczmarek B., Polityka jako artykulacja interesów, [w:] Metafory polityki, red. idem, DW Elipsa, Warszawa 2001.

Kanazawa S., Evolutionary psychological foundations of civil war, „The Journal of Politics” 2009, nr 71 (1).

Khan S.R., Samarina V., Realistic Group Conflict Theory, [w:] Encyclopedia of Social Psychology, red. R.F. Baumeister, K.D. Vohs, Sage Publications Inc., Thousand Oaks, Calif. 2007.

Konflikt społeczny w perspektywie socjologicznej i pedagogiczno-psychologicznej: wybrane kwestie, red. D. Borecka-Biernat, M. Cywińska, Diffin, Warszawa 2015.

Konflikty międzygrupowe. Przejawy, źródła i metody rozwiązywania, red. K. Skarżyńska, U. Jakubowska, J. Wasilewski, Wydawnictwo SWPS Academica, Warszawa 2007.

Koralewicz J., Autorytaryzm, lęk, konformizm, Wydawnictwo Naukowe Scholar/Collegium Civitas Press, Warszawa 2008.

Korzeniowski K., Polska paranoja polityczna. Źródła, mechanizmy i konsekwencje spiskowego myślenia o polityce, Wydawnictwo IP PAN, Warszawa 2010. 
Kossowska M., O motywach sprzyjajacych vs. przeciwdziałających powstawaniu uprzedzeń, „Psychologia Społeczna" 2006, nr 2 (2).

Kossowska M., Różnice indywidualne w potrzebie poznawczego domknięcia, „Przegląd Psychologiczny” 2003, nr 103 (2).

Kruglanski A.W., Webster D.W., Motivated closing of the mind: „Seizing” and „freezing”, „Psychological Review" 1996, nr 103 (2).

Levin S. et al., Ethnic identity, legitimizing ideologies, and social status: A matter of ideological asymmetry, „Political Psychology” 1998, nr 19 (2).

Leyens J.-P. et al., The emotional side of prejudice: The attribution of secondary emotions to ingroups and outgroups, „Personality and Social Psychology Review” 2000, nr 4 (2).

Marody M., Sens teoretyczny a sens empiryczny pojęcia postawy. Analiza metodologiczna zasad doboru wskaźników w badaniach nad postawami, Państwowe Wydawnictwo Naukowe, Warszawa 1976.

Metafory polityki, red. B. Kaczmarek, DW Elipsa, Warszawa 2001.

Mlicki M.K., Konflikty społeczne: pułapki i dylematy działań zbiorowych, Wydawnictwo IFiS PAN, Warszawa 1992.

Mucha J., Konflikt i społeczeństwo. Z problematyki konfliktu społecznego we współczesnych teoriach zachodnich, Państwowe Wydawnictwo Naukowe, Warszawa 1978.

My i oni: rola, miejsce i znaczenie konfliktów w polityce, red. A. Kasińska-Metryka, R. Miernik, cz. 1, Wydawnictwo Uniwersytetu Jana Kochanowskiego, Kielce 2010.

My i oni: rola, miejsce i znaczenie konfliktów w polityce, red. A. Kasińska-Metryka, R. Miernik, cz. 2, Wydawnictwo Uniwersytetu Jana Kochanowskiego, Kielce 2012.

Nelson T.D., Psychologia uprzedzeń, Gdańskie Wydawnictwo Psychologiczne, Gdańsk 2003.

Nocoń J., Laska A., Teoria polityki. Wprowadzenie, Wydawnictwo Wyższej Szkoły Pedagogicznej TWP, Warszawa 2005.

Nowak S., Pojęcie postawy w teoriach i stosowanych badaniach społecznych, [w:] Teorie postaw, red. idem, Państwowe Wydawnictwo Naukowe, Warszawa 1973.

Oblicza kampanii wyborczych 2015 roku, red. M. Kułakowska, P. Borowiec, P. Ścigaj, Wydawnictwo Uniwersytetu Jagiellońskiego, Kraków 2016.

Oxford Handbook of Evolutionary Psychology, red. L. Barrett, R. Dunbar, Oxford 2007.

Pipes D., Potęga spisku. Wplyw paranoicznego myślenia na dzieje ludzkości, BEJ Service, Warszawa 1998.

Podstawy psychologii politycznej, red. K. Skarżyńska, Wydawnictwo Zysk i S-ka, Poznań 2002.

Political Psychology. Key Readings, red. J.T. Jost, J. Sidanius, Psychology Press, New York-Hove 2004.

Poza stereotypy. Dehumanizacja i esencjalizm w postrzeganiu grup społecznych, red. M. Drogosz, M. Bilewicz, M. Kofta, Wydawnictwo Naukowe Scholar, Warszawa 2012.

Pratto F. et al., Social dominance orientation: A personality variable predicting social and political attitudes, „Journal of Personality and Social Psychology" 1994, nr 67 (4).

Pratto F., Sidanius J., Levin S., Social dominance theory and the dynamics of intergroup relations: Taking stock and looking forward, „European Review of Social Psychology” 2006, nr 17 (1).

Psychologia: podręcznik akademicki, red. J. Strelau, t. 3, Gdańskie Wydawnictwo Psychologiczne, Gdańsk 2000.

Psychologia polityczna, red. D.O. Sears, L. Huddy, R. Jervis, Wydawnictwo Uniwersytetu Jagiellońskiego, Kraków 2008.

Psychologiczne charakterystyki elektoratów partyjnych, CBOS, Komunikat z badań nr 138/2015, Warszawa 2015.

Psychology of Intergroup Relations, red. S. Worchel, L.W. Austin, Nelson-Hall, Chicago 1986.

Pyszczynski T., What are we so afraid of? A Terror Management Theory perspective on the politics of fear, „Social Research” 2004, nr 71 (4).

Pyszczynski T., Solomon S., Greenberg J., In the Wake of 9/11. The Psychology of Terror, American Psychological Association, Washington DC 2010.

Radkiewicz P., Autorytaryzm a brzytwa Ockhama, Wydawnictwo Naukowe Scholar, Warszawa 2012. 
Radkiewicz P., Autorytaryzm jako ideologiczna wizja świata społecznego i jako postawa wobec własnej grupy. Co jest bliższe istoty zjawiska?, [w:] Wobec obcych. Zagrożenia psychologiczne a stosunki międzygrupowe, red. M. Kofta, M. Bilewicz, Wydawnictwo Naukowe PWN, Warszawa 2011.

Ray J.J., Authoritarianism and group identification: A new view of an old construct: Comment, „Political Psychology" 1990, nr 11 (3).

Reich W., Psychologia mas wobec faszyzmu, Wydawnictwo Aletheia, Warszawa 2009.

Reykowski J., Konflikty polityczne, [w:] Podstawy psychologii politycznej, red. K. Skarżyńska, Wydawnictwo Zysk i S-ka, Poznań 2002.

Robins R.S., Post J.M., Paranoja polityczna. Psychologia nienawiści, Książka i Wiedza, Warszawa 2007.

Roiser M., Willig C., The strange death of the authoritarian personality: 50 years of psychological and political debate, „History of the Human Science” 2002, nr 15 (4).

Rokeach M., The Open and Closed Mind: Investigations into the Nature of Belief Systems and Personality Systems, Basic Books, New York 1960.

The Sage Handbook of Prejudice, Stereotyping and Discrimination, red. J.F. Dovidio et al., Sage Publications Ltd., London 2013.

Scott J., Władza, Sic!, Warszawa 2006.

Sherif M. et al., The Robbers Cave Experiment: Intergroup Conflict and Cooperation, Wesleyan University Press, Middletown, Connecticut 1988.

Sidanius J. et. al., Social dominance orientation, anti-egalitarianism and the political psychology of gender: An extension and cross-cultural replication, „European Journal of Social Psychology” 2000, nr 30.

Sidanius J., Pratto F., Social Dominance. An Intergroup Theory of Social Hierarchy and Oppression, Cambridge University Press, Cambridge 1999.

Sidanius J., Pratto F., Social Dominance Theory, [w:] Handbook of Theories of Social Psychology, red. P.A.M. van Lange, A.W. Kruglanski, E.T. Higgins, t. 2, Sage Publications Ltd., London 2012.

Skarżyńska K., Wprowadzenie - Czym jest konflikt, od czego zależy jego przebieg i sposób rozwiązywania, [w:] Konflikty międzygrupowe. Przejawy, źródła i metody rozwiązywania, red. eadem, U. Jakubowska, J. Wasilewski, Wydawnictwo SWPS Academica, Warszawa 2007.

Sobkowiak L., Konflikt polityczny - analiza zjawiska, [w:] Studia z teorii polityki, red. A.W. Jabłoński, L. Sobkowiak, t. 1, Wydawnictwo Uniwersytetu Wrocławskiego, Wrocław 1996.

Social Identity and Intergroup Relations, red. H. Tajfel, Cambridge University Press, Cambridge 1982.

The Social Psychology of Intergroup Relations, red. W.G. Austin, S. Worchel, Brooks-Cole Publishing Company, Monterey CA 1979.

Stellmacher J., Petzel T., Authoritarianism as a group phenomenon, „Political Psychology” 2005, nr 26 (2).

Stenner K., The Authoritarian Dynamic, Cambridge University Press, Cambridge 2005.

Stephan W.G., Stephan C.W., Wywieranie wpływu przez grupy. Psychologia relacji, Gdańskie Wydawnictwo Psychologiczne, Gdańsk 2003.

Stereotypy i uprzedzenia. Najnowsze ujęcie, red. C.N. Macrea, Ch. Stangor, M. Hewstone, Gdańskie Wydawnictwo Psychologiczne, Gdańsk 1999.

Struktura teorii spiskowych. Antologia, red. F. Czech, Zakład Wydawniczy „Nomos”, Kraków 2014.

Studia nad spostrzeganiem relacji „Ja-Inni”: tożsamość, indywiduacja, przynależność, red. M. Jarymowicz, Wydawnictwo Polskiej Akademii Nauk, Warszawa 1998.

Studia z teorii polityki, red. A.W. Jabłoński, L. Sobkowiak, t. 1, Wydawnictwo Uniwersytetu Wrocławskiego, Wrocław 1996.

Sztumski J., Konflikt społeczny, Wydawnictwo Uniwersytetu Śląskiego, Katowice 1987.

Sztumski J., Konflikty społeczne i negocjacje jako sposoby ich przezwyciężania, Wydawnictwo Wydziału Zarządzania Politechniki Częstochowskiej, Częstochowa 2000.

Ścigaj P., Polacy 2015. Wybrane postawy polskiego społeczeństwa $w$ roku wyborów prezydenckich i parlamentarnych, [w:] Oblicza kampanii wyborczych 2015 roku, red. M. Kułakowska, P. Borowiec, P. Ścigaj, Wydawnictwo Uniwersytetu Jagiellońskiego, Kraków 2016. 
Tajfel H., Social psychology of intergroup relations, „Annual Review of Psychology” 1982, nr 33.

Tajfel H., Tożsamość społeczna a zachowanie międzygrupowe, „Przegląd Psychologiczny” 1976, nr 19 (2).

Tajfel H. et al., Social categorization and intergroup behaviour, „European Journal of Social Psychology” 1971, nr 1 (2).

Tajfel H., Turner J.C., An Integrative Theory of Intergroup Conflict, [w:] The Social Psychology of Intergroup Relations, red. W.G. Austin, S. Worchel, Brooks-Cole Publishing Company, Monterey CA 1979.

Tajfel H., Turner J.C., The Social Identity Theory of Intergroup Behavior, [w:] Psychology of Intergroup Relations, red. S. Worchel, L.W. Austin, Nelson-Hall, Chicago 1986.

Teoria opanowywania trwogi. Dyskurs w literaturze amerykańskiej, red. M. Rusaczyk, Wydawnictwo Naukowe Scholar, Warszawa 2008.

Teorie postaw, red. S. Nowak, Państwowe Wydawnictwo Naukowe, Warszawa 1973.

Tooby J., Cosmides L., The evolution of war and its cognitive foundations, „Institute for Evolutionary Studies Technical Report 88-1” 1988, http://www.cep.ucsb.edu/papers/EvolutionofWar.pdf (dostęp: 6 stycznia 2017).

Toorn J. van der, Jost J.T., Twenty years of system justification theory: Introduction to the special issue on "Ideology and system justification processes”, „Group Processes \& Intergroup Relations” 2014, nr 17 (4).

Trounson J.S., Critchley C., Pfeifer J.E., Australian attitudes toward asylum seekers: roles of dehumanization and social dominance theory, „Social Behavior and Personality” 2015, nr 43 (10).

Turner J.C., Teoria autokategoryzacji, [w:] Encyklopedia Blackwella: psychologia społeczna, red. A.S.R. Manstead et al., Wydawnictwo Jacek Santorski \& CO, Warszawa 1996.

Turner J.C., Towards a Cognitive Redefinition of the Social Group, [w:] Social Identity and Intergroup Relations, red. H. Tajfel, Cambridge University Press, Cambridge 1982.

Turner J.C. et al., Rediscovering the Social Group. A Self-Categorization Theory, Basil Blackwell, Oxford 1987.

Turner J.H., Struktura teorii socjologicznej. Wydanie nowe, PWN, Warszawa 2004.

Wiatr J., Socjologia polityki, Europejska Wyższa Szkoła Prawa i Administracji, Warszawa 2009.

Wilmot W.W., Hocker J.L., Konflikty między ludźmi, Wydawnictwo Naukowe PWN, Warszawa 2011.

Wobec obcych. Zagrożenia psychologiczne a stosunki międzygrupowe, red. M. Kofta, M. Bilewicz, Wydawnictwo Naukowe PWN, Warszawa 2011.

Worell M.P., Authoritarianism, critical theory, and political psychology: Past, present, future, „Social Thought \& Research" 1998, nr 21 (1-2).

Zimbardo P., Efekt Lucyfera. Dlaczego dobrzy ludzie czynia zło?, Wydawnictwo Naukowe PWN, Warszawa 2008.

Ziółkowski J., Wrogość w stosunkach politycznych. Modelowa analiza funkcjonalna, DW Elipsa, Warszawa 2013.

\section{Psychological foundations of social conflicts: on dispositional and situational aspects of intergroup bias and prejudice}

Keywords: social conflicts, political conflicts, intergroup bias, prejudice, political attitudes

\section{Summary}

The aim of the paper is to discuss main theories explaining the psychological basis of social and political conflicts, especially causes of intergroup bias and prejudice. Theories of authoritarianism and social dominance orientation are discussed referring dispositional causes of intergroup bias and prejudice, while realistic conflict group theory, social identity theory and system-justification theory are called for explaining situational determinants of intergroup bias and prejudice. Evolutionary aspects of hostility and aggression in social and political conflicts are also debated. 